\title{
A Mineralogical Investigation on Volatilization of Impurity Elements from Cu-Rich Polymetallic Concentrates During Roasting in Inert Atmosphere
}

\author{
PANDE NISHANT PRASAD, IRIS MCELROY, ANDREAS LENNARTSSON, \\ and CAISA SAMUELSSON
}

\begin{abstract}
Four different $\mathrm{Cu}$-rich polymetallic concentrates are tested for volatilization of $\mathrm{Sb}$ and $\mathrm{As}$ during laboratory-scale roasting. The experiments are performed between $200{ }^{\circ} \mathrm{C}$ and $700{ }^{\circ} \mathrm{C}$, at intervals of $100{ }^{\circ} \mathrm{C}$ and in an inert atmosphere. Sb volatilization is much less (maximum approximately $45 \mathrm{pct}$ ) than As volatilization (maximum approximately $95 \mathrm{pct}$ ) in these conditions at $700{ }^{\circ} \mathrm{C}$. As volatilization is however limited from the concentrate having As mainly in a tetrahedrite solid solution $\left((\mathrm{Cu}, \mathrm{Ag}, \mathrm{Fe}, \mathrm{Zn})_{12}(\mathrm{Sb}, \mathrm{As})_{4} \mathrm{~S}_{13}\right) . \mathrm{Sb}$ and $\mathrm{As}$ retained in the roasted calcine are found in the low-melting liquid phase, formed at approximately $500{ }^{\circ} \mathrm{C}$. This melt phase gets enlarged and enriched in $\mathrm{Sb}$ with an increase in temperature. However, there is noticeable As volatilization from this melt phase with the temperature approaching $700{ }^{\circ} \mathrm{C}$. Furthermore, there is an early and relatively high $\mathrm{Sb}$ volatilization from the concentrate having $\mathrm{Sb}$ substantially as gudmundite. Micron-scale elemental redistribution in gudmundite in the 350 ${ }^{\circ} \mathrm{C}$ roasted calcine confirms its transformation at this temperature. Other $\mathrm{Sb}$ minerals did not undergo any detectable transformation at this temperature, suggesting that the significant $\mathrm{Sb}$ volatilization starting between $300{ }^{\circ} \mathrm{C}$ and $400{ }^{\circ} \mathrm{C}$ was primarily from gudmundite. This benign attribute of gudmundite featured in this work in the context of roasting should also be relevant from the geometallurgical perspective during concentrate production, where concentrates bearing $\mathrm{Sb}$ are considered substandard for further $\mathrm{Cu}$ extraction irrespective of the $\mathrm{Sb}$ mineralogy.
\end{abstract}

https://doi.org/10.1007/s11663-020-02051-z

(C) The Author(s) 2021

\section{INTRODUCTION}

SULFIDE deposits of copper can broadly be classified as simple or complex. The simple $\mathrm{Cu}$ deposits generally comprise copper as the main base metal in the form of chalcopyrite, for instance, the Aitik deposit in northern Sweden. ${ }^{[1]}$ Complex $\mathrm{Cu}$ deposits are polymetallic, usually containing additional base metals ( $\mathrm{Zn}$, $\mathrm{Pb}, \mathrm{Ni}, \mathrm{Co}$, etc.), precious metals ( $\mathrm{Ag}, \mathrm{Au}, \mathrm{Pt}$, etc.) and the Group 15 elements (As, Sb, Bi). Some examples of complex polymetallic deposits in Sweden are Garpenberg, ${ }^{[2,3]}$ Maurliden ${ }^{[4]}$ and Rockliden. ${ }^{[5]}$ Mineral processing of the ore from these complex deposits generates multiple concentrates, each being rich in a particular base or precious metal. However, these individual

PANDE NISHANT PRASAD, ANDREAS LENNARTSSON, and CAISA SAMUELSSON are with the Luleå Tekniska Universitet, 97187 Luleå, Sweden. Contact e-mail: pande.nishant.prasad@1tu.se IRIS MCELROY is with the Boliden Mines Technology, 93681 Boliden, Sweden.

Manuscript submitted June 26, 2020; accepted December 3, 2020.

Article published online January 6, 2021. metal-rich concentrates are still polymetallic, containing low proportions of the other metals, and therefore still considered complex for further extraction. For instance, the $\mathrm{Cu}$-rich concentrates studied by Prasad et al. ${ }^{[6]}$ were essentially polymetallic, containing approximately 5 to 10 wt pet $\mathrm{Zn}, 5$ to 15 wt pet $\mathrm{Pb}, \mathrm{Ag}>250 \mathrm{ppm}$, As $>0.2$ wt pet and $\mathrm{Sb}>1.3$ wt pet.

The elements $\mathrm{As}$ and $\mathrm{Sb}$ in the complex concentrates are considered noxious and often referred to as 'impurity elements,' owing to the general high toxicity of their compounds. ${ }^{[7,8]}$ Consequently, the processing of ores bearing $\mathrm{As}$ and $\mathrm{Sb}$ raises serious environmental concerns. Also, the presence of these elements in the ore tends to degrade the properties of the refined final $\mathrm{Cu} .{ }^{[9]}$

In the current practice, polymetallic $\mathrm{Cu}$-rich concentrates bearing impurity elements are introduced into the pyrometallurgical extraction process by blending in small proportions with concentrates from the simpler deposits. However, the ongoing depletion of simpler $\mathrm{Cu}$ deposits necessitates an increase in the proportions of complex concentrates in the blends to enable a sustainable $\mathrm{Cu}$ production in the near future. 
To overcome the associated environmental and metallurgical complexities with blends rich in polymetallic concentrates, the impurity elements, As and $\mathrm{Sb}$ should be removed prior to the smelting steps. ${ }^{[10]}$ The upgrading of As- and Sb-bearing complex concentrates for further processing has been investigated through certain hydrometallurgical treatments. The concentrates were subjected to leaching environments such as acidic chloride $\mathrm{e}^{[1-16]}$ and alkaline sulfide $\mathrm{e}^{[17-20]}$ for selective dissolution of $\mathrm{As}$ and $\mathrm{Sb}$. Alternatively, roasting of $\mathrm{Cu}$-concentrates can also partially volatilize the impurity elements As and Sb. ${ }^{[2-30]}$ Therefore, advancements in the roasting technology can also facilitate the increase in proportions of the complex concentrates in blends processed for pyrometallurgical $\mathrm{Cu}$ extraction.

Heretofore, studies on the $\mathrm{As}$ and $\mathrm{Sb}$ volatilization during roasting have been performed on the pure As and $\mathrm{Sb}$ minerals or on the concentrates rich in specific As or $\mathrm{Sb}$ minerals such as enargite $\left(\mathrm{Cu}_{3} \mathrm{AsS}_{4}\right),{ }^{[31,32]}$ arsenopyrite $(\mathrm{FeAsS}),{ }^{[33-35]}$ stibnite $\left(\mathrm{Sb}_{2} \mathrm{~S}_{3}\right)^{[36-42]}$ and $\mathrm{Sb}$ sulfosalts. ${ }^{[43]}$ There have also been studies reporting improvements in the $\mathrm{Sb}$ volatilization when $\mathrm{As}$ and $\mathrm{Sb}$ co-exist, owing to complexation in the vapor-phase $\mathrm{Sb}$ volatilization. ${ }^{[4-46]}$ However, in a complex polymetallic concentrate, the behavior of $\mathrm{As}$ and $\mathrm{Sb}$ minerals may change due to interaction with the other minerals. For instance, Prasad et al. ${ }^{[6]}$ presented an investigation on early sintering susceptibility during roasting due to mineralogical interactions among numerous major and minor minerals existing in $\mathrm{Cu}$-rich polymetallic concentrates. It would be important to investigate the effect of these mineralogical interactions in complex concentrates during roasting on the extents of $\mathrm{As}$ and $\mathrm{Sb}$ volatilization.

There have also been investigations of $\mathrm{As}$ and $\mathrm{Sb}$ volatilization using complex concentrates as the starting material for laboratory-scale roasting. ${ }^{[21,24,26-30,46]}$ However, mineralogical transformations during the volatilization progress in roasted calcines are only moderately discussed. A detailed study of such transformations tracking the deportment of $\mathrm{As}$ and $\mathrm{Sb}$ in the mineral phases with an increase in temperature is missing, which is the focus of this work. This article discusses the extent of $\mathrm{As}$ and $\mathrm{Sb}$ removal in the laboratory-scale roasting experiments presented in Prasad et al., ${ }^{[6]}$ where the complex concentrates experienced sintering during roasting in inert atmosphere. These experiments were performed in inert atmosphere to facilitate a fundamental study on the mineral assemblies in low oxidation potential roasting environments, which are considered favorable for the impurity volatilization. ${ }^{[47]}$

This article additionally deliberates on the current practice of strict tolerance on the $\mathrm{Sb}$ wt pct content in incoming concentrates at the smelter units, irrespective of the Sb mineralogy. ${ }^{[25]}$ From the geometallurgical perspective, it is difficult to prevent the entry of $\mathrm{Sb}$ sulfosalt minerals (containing $\mathrm{Cu}, \mathrm{Ag}$ or $\mathrm{Pb}$ ) into the $\mathrm{Cu}$-rich flotation stream owing to the similarity of their flotation behavior with chalcopyrite. ${ }^{[5,48,49]}$ The other $\mathrm{Sb}$ minerals, particularly the Fe-bearing gudmundite $(\mathrm{FeSbS})$ and berthierite $\left(\mathrm{FeSb}_{2} \mathrm{~S}_{4}\right)$, lack such flotation attributes and therefore should ideally end up into the tailings. ${ }^{[49]}$ However, these Fe-bearing Sb minerals often get misplaced into the $\mathrm{Cu}-\mathrm{Pb}$ concentrate stream because of their complex association/locking with the main $\mathrm{Cu}$ and $\mathrm{Pb}$ minerals. ${ }^{[48]}$ From the metallurgical standpoint, gudmundite in particular, being thermally unstable above $280 \pm 10{ }^{\circ} \mathrm{C},{ }^{[50]}$ may undergo $\mathrm{Sb}$ volatilization unlike numerous other $\mathrm{Sb}$ minerals found in the complex concentrates. Therefore, the presence of gudmundite in the $\mathrm{Cu}$-rich flotation streams may not create $\mathrm{Sb}$-related complexities in the pyrometallurgical flowsheet of $\mathrm{Cu}$ extraction. This hypothesis of the feasibility of $\mathrm{Sb}$ volatilization from gudmundite during roasting is also tested in the current work. In the mineral processing context, all $\mathrm{Sb}$ minerals are at present aimed for the tailing streams, irrespective of their roasting behavior. The possibility of substantial $\mathrm{Sb}$ volatilization from the specific minerals during roasting may be relevant information, also at the stage of concentrate production during mineral processing.

\section{EXPERIMENTAL DESIGN AND ANALYTICAL TECHNIQUES}

\section{A. Materials}

The four $\mathrm{Cu}$-rich complex polymetallic concentrate samples used in this study are listed with their chemical compositions in Table I.

These concentrates belong to the Rockliden, Maurliden and Garpenberg deposits of Boliden Mineral AB, Sweden. To clearly identify the particle-size changes during microscopic studies on the calcines obtained after the roasting, a narrow band of 38 to $53 \mu \mathrm{m}$ size fraction of these concentrates was used for all the characterizations and experiments, except for one experiment (Experiment Group ID 350-10 in Table II) in which the Rockliden $\mathrm{S} 7574$ concentrate size fraction below 38 $\mu \mathrm{m}$ was used. This was because only a limited amount of Rockliden S7574 concentrate was available, generated in a laboratory flotation setup, ${ }^{[48]}$ and the 38 to $53 \mu \mathrm{m}$ size fraction of this concentrate got consumed in the previous roasting experiments. Usage of the size fraction $<38 \mu \mathrm{m}$ in this experiment however did not affect the study in any way since this experiment was performed at $350{ }^{\circ} \mathrm{C}$, at which particle size alterations do not take place because of any physicochemical mineralogical interaction. ${ }^{[6]}$

The chemical compositions of the initial concentrates and the roasted calcines were provided by ALS Global $\mathrm{AB}$, Luleå. The method included melting with $\mathrm{LiBO}_{2}$, digestion in $\mathrm{HNO}_{3} / \mathrm{HCl} / \mathrm{HF}$ and measurement using ICP-SFMS in accordance with SS EN ISO 17294-2: $2016^{[51]}$ and EPA method 200.8: 1994. ${ }^{[52]}$

\section{B. Roasting Experiments in the Vertical Tube Furnace}

Experiments on laboratory-scale roasting were performed in a vertical tube furnace setup. These experiments were referred to as the isothermal roasting experiments in Prasad et al. ${ }^{[6]}$ In the beginning of each 
Table I. Chemical Composition of Cu-Rich Complex Polymetallic Concentrates Belonging to the 38 to $53 \mu \mathrm{m}$ Size Fraction

\begin{tabular}{|c|c|c|c|c|}
\hline $\mathrm{Cu}$ Concentrate & Rockliden S7574 & Rockliden 8232 & Garpenberg & Maurliden \\
\hline $\mathrm{Cu}$ (Wt Pct) & 13.8 & 16.6 & 19.3 & 15.4 \\
\hline $\mathrm{Zn}$ (Wt Pct) & 8.4 & 4.7 & 9.5 & 4.5 \\
\hline $\mathrm{Pb}$ (Wt Pct) & 5.2 & 5 & 15.3 & 11.3 \\
\hline $\mathrm{Fe}$ (Wt Pct) & 25.1 & 21.6 & 19.8 & 31.3 \\
\hline $\mathrm{Si}(\mathrm{Wt} \mathrm{Pct})$ & 0.3 & 3.8 & 0.8 & 0.3 \\
\hline $\mathrm{Mg}$ (Wt Pct) & 0.1 & 2.0 & 0.2 & 0.1 \\
\hline $\mathrm{S}(\mathrm{Wt} \mathrm{Pct})$ & 31.4 & 22.6 & 26.1 & 33.3 \\
\hline $\mathrm{Ag}(\mathrm{Wt}$ Pct) & 0.03 & 0.026 & 1.82 & 0.036 \\
\hline As (Wt Pct) & 0.74 & 0.44 & 0.23 & 2.1 \\
\hline $\mathrm{Sb}$ (Wt Pct) & 1.36 & 1.72 & 2.04 & 3.77 \\
\hline
\end{tabular}

Table II. Details of Laboratory-Scale Roasting Experiments in a Vertical Tube Furnace

\begin{tabular}{lccccc}
\hline $\begin{array}{l}\text { Experiment } \\
\text { ID }\end{array}$ & $\begin{array}{c}\text { Group } \\
\text { Carrier Gas; Flow Rate, } 1 /\end{array}$ & $\begin{array}{c}T, \\
\text { min }\end{array}$ & $\begin{array}{c}\text { Holding Time, } \\
\text { min }\end{array}$ & $\begin{array}{c}\text { Sample Initial wt, } \\
\text { g }\end{array}$ & Concentrates Tested \\
\hline $200-1$ & $\mathrm{~N}_{2} ; 5$ & 200 & 70 & 10 & all 4 concentrates $(38-53 \mu \mathrm{m})$ \\
$300-1$ & $\mathrm{~N}_{2} ; 5$ & 300 & 70 & 10 & all 4 concentrates $(38-53 \mu \mathrm{m})$ \\
$400-1$ & $\mathrm{~N}_{2} ; 5$ & 400 & 70 & 10 & all 4 concentrates $(38-53 \mu \mathrm{m})$ \\
$500-1$ & $\mathrm{~N}_{2} ; 5$ & 500 & 70 & 10 & all 4 concentrates $(38-53 \mu \mathrm{m})$ \\
$600-1$ & $\mathrm{~N}_{2} ; 5$ & 600 & 70 & 10 & all 4 concentrates $(38-53 \mu \mathrm{m})$ \\
$700-1$ & $\mathrm{~N}_{2} ; 5$ & 700 & 70 & 10 & all 4 concentrates $(38-53 \mu \mathrm{m})$ \\
$350-10$ & $\mathrm{~N}_{2} ; 2$ & 350 & 600 & 50 & Rockliden $\mathrm{S} 7574(<38 \mu \mathrm{m})$ \\
\hline
\end{tabular}

experiment, the concentrate sample was positioned in a cold zone while the furnace was heating up to the experimental temperature. Once, the desired furnace temperature was achieved, the sample was lifted into the hot zone. The gas atmosphere inside the furnace was maintained inert by flowing nitrogen (Chemical Nitrogen 4.6 from AGA-Linde, purity $\geq 99.996$ pct, $\mathrm{H}_{2} \mathrm{O}(\mathrm{g}) \leq$ $\left.5 \mathrm{ppm}, \mathrm{O}_{2}(\mathrm{~g}) \leq 5 \mathrm{ppm}\right)$ as a carrier gas.

The various types of experiments with differing operating conditions are listed in Table II.

The experimental apparatus is presented schematically in Figure 1. An optional water-cooled condensation plate shown in Figure 1 was introduced only in the Experiment Group IDs 700-1 and 350-10 to facilitate condensation of volatile species from the gas phase. In the Experiment Group ID 350-10, a longer holding time of $10 \mathrm{~h}$ and larger sample mass of $50 \mathrm{~g}$ were employed to obtain a sufficient amount of condensates for proper characterization. However, investigations related to these condensate phases are not within the scope of this article.

\section{SEM/EDS Analysis}

Polished and carbon-coated epoxy mounts were prepared for the initial concentrates and the calcined residues obtained from all the experiments. These epoxy mounts were examined in a Zeiss Merlin FEG SEM (scanning electron microscope) using an Oxford Instruments X-Max EDS (energy-dispersive X-ray

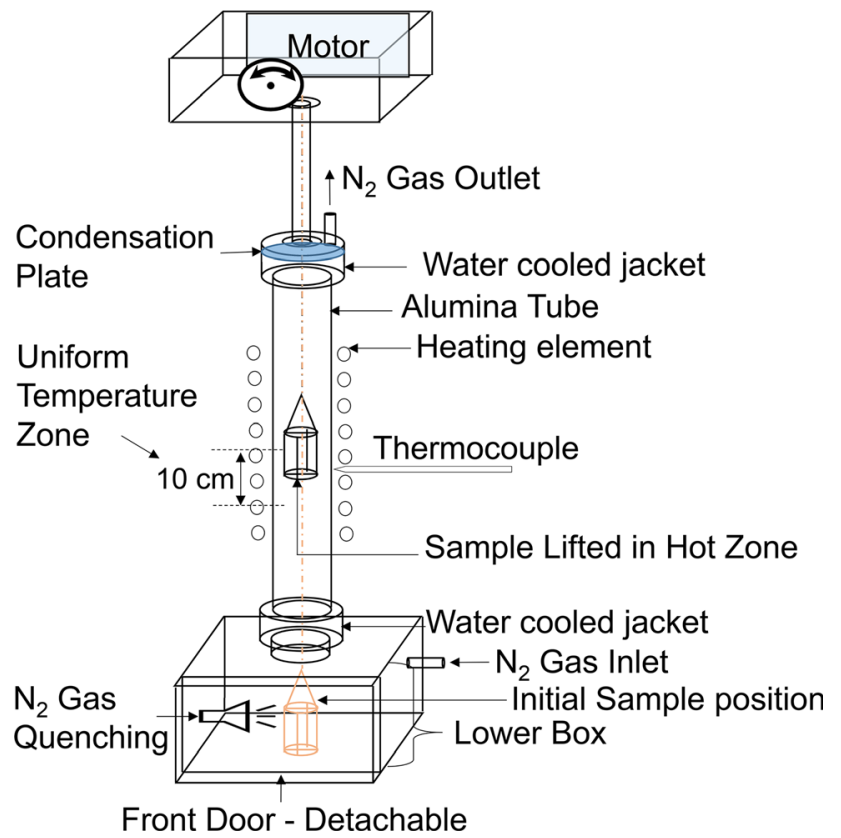

Fig. 1-Vertical tube furnace for roasting of concentrates.

spectroscopy) detector operated by AZtec software. It was operated with a working distance of $8.5 \mathrm{~mm}$, probe current of $1 \mathrm{nA}$ and accelerating voltage of $20 \mathrm{kV}$. Beam measurement calibration for the EDS analyses was done on pure copper. The EDS spot measurements produced 
elemental compositions, which are reported in mol pct after normalization so that the summation of values for all the identified elements is $100 \mathrm{~mol}$ pct. Also, EDS-linescans were performed to detect any microscopic variation in the elemental concentrations in the identified mineral phases.

\section{Automated Quantitative Mineralogical Analysis (QEMSCAN)}

The epoxy mounts for initial concentrate samples were additionally analyzed in a QEMSCAN system (model: QEMSCAN 650, FEI with W-filament and two Brukar XFlash 5030 EDS detectors) at Boliden Mineral AB, Boliden, Sweden. The programs iMeasure (version 5.4) and iDiscover (version 5.4) were used for data collection and data processing, respectively. The equipment was operated with a working distance of $13 \mathrm{~mm}$, probe current of $10 \pm 0.05 \mathrm{nA}$ and accelerating voltage of $25 \mathrm{kV}$. Measurement was performed in the PMA (particle mineral analysis) mode at a resolution of 2.5 $\mu \mathrm{m}$, with a field width of $1500 \mu \mathrm{m}$ (generating $600 \times 600$ analysis points per field). Mineral identifications were made using a reference mineral library, SIP (Species Identification Protocol), customized through the numerous in-house mineralogical studies at Boliden AB. This SIP reference library was further modified for adapting to the mineralogy of the four concentrates using the sampled SEM-EDS measurements of mineral compositions on their epoxy mounts. Table III presents the mineral list with the corresponding elemental composition range set for the SIP definition. Ensuring no compositional overlaps, the elemental ranges were kept wide enough to effectively classify the minerals, especially in the microstructural fields with complex textures.

The QEMSCAN measurements provided mineralogical compositions, liberation and association details by analyzing more than 25,000 particles in each of the four epoxy-mounted concentrate samples (all belonging to the 38 to $53 \mu \mathrm{m}$ size fraction).

\section{RESULTS AND DISCUSSION}

\section{A. Sb and As Mineral Deportment in Initial Concentrates}

Figure 2 presents the $\mathrm{Sb}$ deportment in various minerals in the four concentrates obtained from QEMSCAN study.

Evidently, the sulfosalts such as tetrahedrite, bournonite and meneghinite are the major hosts for $\mathrm{Sb}$ in the four concentrates. However, $\mathrm{Sb}$ also exists significantly in the form of certain non-sulfosalt minerals: (1) gudmundite (approximately $22 \mathrm{wt}$ pct total $\mathrm{Sb}$ ) in

Table III. Mineral List with the Composition Range Used for the Mineral Library Definition Used in QEMSCAN Measurements

Elemental Range of the Composition Set in SIP

\begin{tabular}{|c|c|c|c|c|c|c|c|c|c|c|c|c|}
\hline Mineral & Abbreviation & Limits, Wt Pct & $\mathrm{Cu}$ & $\mathrm{Fe}$ & S & $\mathrm{Zn}$ & $\mathrm{Pb}$ & $\mathrm{Ag}$ & $\mathrm{Sb}$ & As & Sn & $\mathrm{O}$ \\
\hline \multirow[t]{2}{*}{ Chalcopyrite $\left(\mathrm{CuFeS}_{2}\right)$} & Ccp & Min. & 25 & 23 & 25 & - & - & - & - & - & - & - \\
\hline & & Max. & 37 & 33 & 40 & - & - & - & - & - & - & - \\
\hline \multirow[t]{2}{*}{ Galena (PbS) } & $\mathrm{Gn}$ & Min. & 0 & 0 & 9 & 0 & 65 & - & - & - & - & - \\
\hline & & Max. & 2 & 2 & 13 & 5 & 90 & - & - & - & - & - \\
\hline \multirow[t]{2}{*}{ Sphalerite $((\mathrm{Zn}, \mathrm{Fe}) \mathrm{S})$} & Sph & Min. & 0 & 0.1 & 20 & 55 & - & - & - & - & - & - \\
\hline & & Max. & 3 & 7 & 35 & 65 & - & - & - & - & - & - \\
\hline \multirow[t]{2}{*}{ Pyrite $\left(\mathrm{FeS}_{2}\right)$} & Py & Min. & - & 35 & 40 & - & - & - & - & - & - & - \\
\hline & & Max. & - & 50 & 55 & - & - & - & - & - & - & - \\
\hline \multirow[t]{2}{*}{ Tetrahedrite $\left((\mathrm{Cu}, \mathrm{Ag}, \mathrm{Fe}, \mathrm{Zn})_{12}(\mathrm{Sb}, \mathrm{As})_{4} \mathrm{~S}_{13}\right) *$} & $\mathrm{Ttr}$ & Min. & 25 & 0.1 & 20 & 0.1 & - & 0.1 & 15 & 0 & - & - \\
\hline & & Max. & 40 & 8 & 30 & 5 & - & 10 & 32 & 5 & - & - \\
\hline \multirow{2}{*}{ 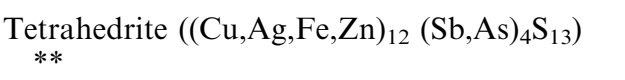 } & $\mathrm{Ttr}$ & Min. & 1 & 0.1 & 20 & 0.1 & - & 0.5 & 15 & 0 & - & - \\
\hline & & Max. & 40 & 8 & 30 & 5 & - & 40 & 32 & 5 & - & - \\
\hline \multirow{2}{*}{ Bournonite $\left(\mathrm{CuPbSbS}_{3}\right)$} & Bour & Min. & 10 & 0 & 8 & - & 25 & - & 15 & - & - & - \\
\hline & & Max. & 14 & 1 & 18 & - & 40 & - & 25 & - & - & - \\
\hline \multirow{2}{*}{ Meneghenite $\left(\mathrm{CuPb}_{13} \mathrm{Sb}_{7} \mathrm{~S}_{24}\right)$} & Mene & Min. & 0.1 & 0 & 11 & - & 40 & - & 12 & - & - & - \\
\hline & & Max. & 3 & 2 & 19 & - & 70 & - & 25 & - & - & - \\
\hline \multirow[t]{2}{*}{ Boulangerite $\left(\mathrm{Pb}_{5} \mathrm{Sb}_{4} \mathrm{~S}_{11}\right)$} & Boul & Min. & - & - & 15 & - & 50 & - & 20 & - & - & - \\
\hline & & Max. & - & - & 25 & - & 60 & - & 30 & - & - & - \\
\hline \multirow[t]{2}{*}{ Gudmundite (FeSbS) } & Gud & Min. & - & 23 & 12 & - & - & - & 45 & - & - & - \\
\hline & & Max. & - & 28 & 18 & - & - & - & 60 & - & - & - \\
\hline \multirow{2}{*}{ Silver Antimonides $\left(\mathrm{Ag}_{\mathrm{n}} \mathrm{Sb}_{\mathrm{m}}\right) * *$} & $\mathrm{Ag}-\mathrm{Sb}$ & Min. & 0 & 0 & - & - & - & 70 & 20 & - & - & - \\
\hline & & Max. & 2 & 2 & - & - & - & 80 & 28 & - & - & - \\
\hline \multirow[t]{2}{*}{ Arsenopyrite (FeAsS) } & Asy & Min. & - & 28 & 18 & - & - & - & - & 37 & - & - \\
\hline & & Max. & - & 37 & 21 & - & - & - & - & 44 & - & - \\
\hline \multirow{2}{*}{ Cassiterite $\left(\mathrm{SnO}_{2}\right)$} & Cas & Min. & - & - & - & - & - & - & - & - & 75 & 20 \\
\hline & & Max. & - & - & - & - & - & - & - & - & 80 & 25 \\
\hline
\end{tabular}




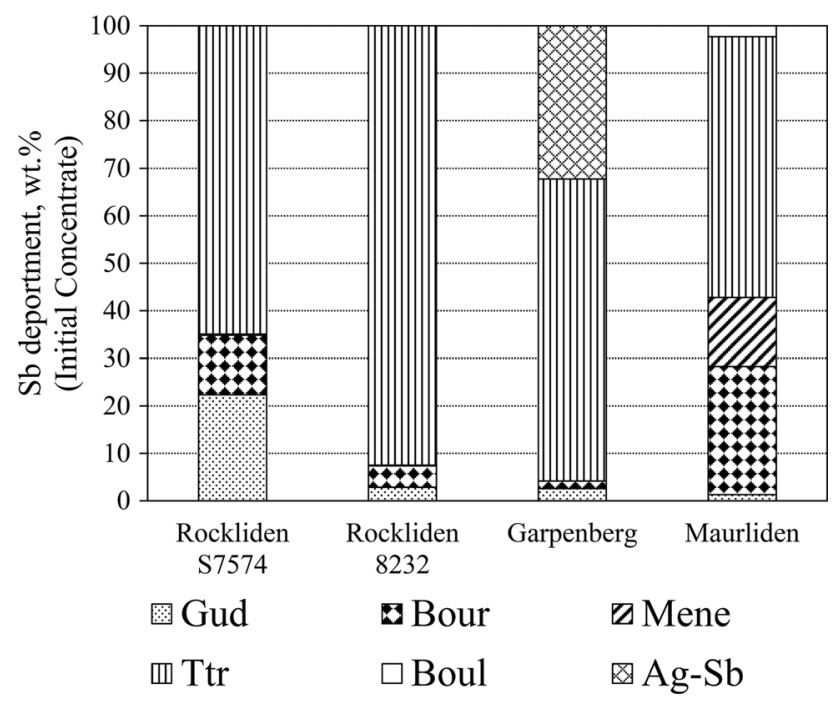

Fig. 2-Sb deportment in different mineral forms obtained from QEMSCAN analysis of the initial concentrates (38 to $53 \mu \mathrm{m}$ ).

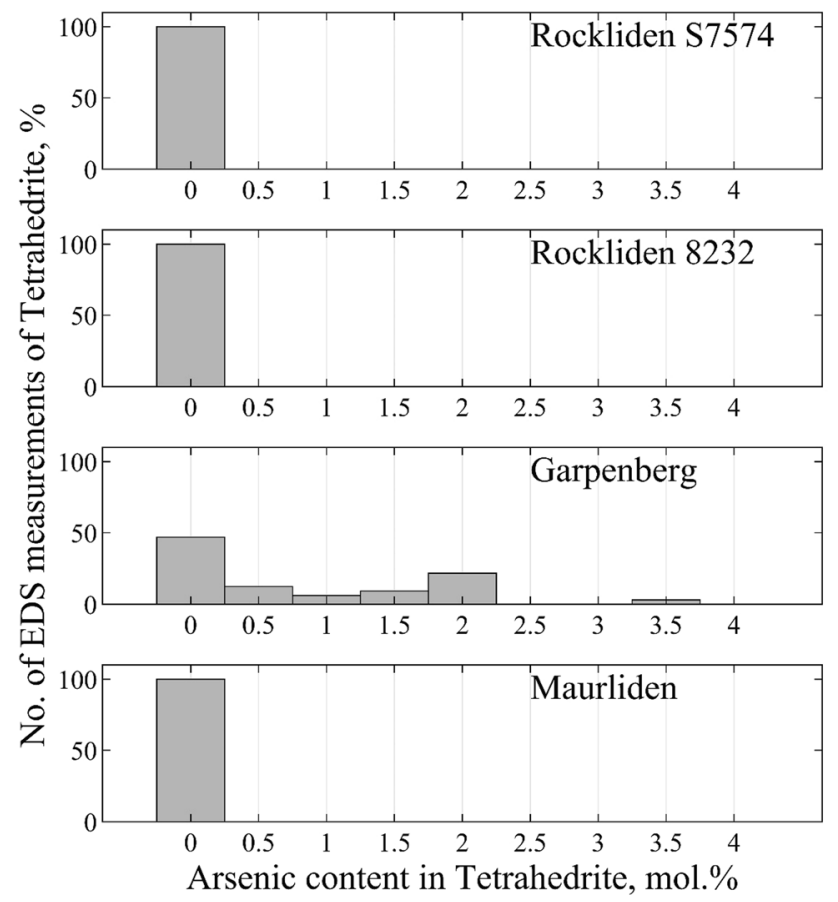

Fig. 3-Histogram showing percentage number of EDS spot measurements on tetrahedrite sites corresponding to different levels of As content (mol pct, $x$-axis) for the four concentrates.

the Rockliden S7574 concentrate and (2) Ag antimonides (approximately $33 \mathrm{wt}$ pct total $\mathrm{Sb}$, shown as $\mathrm{Ag}-\mathrm{Sb}$ ) in the Garpenberg concentrate.

Regarding the As mineralogy, sampled EDS measurements on the initial concentrates confirmed that arsenopyrite is the main As-bearing mineral in the four concentrates. As is also known to be present in the tetrahedrite solid solution $\left((\mathrm{Cu}, \mathrm{Ag}, \mathrm{Fe}, \mathrm{Zn})_{12}(\mathrm{Sb}, \mathrm{As})_{4} \mathrm{~S}_{13}\right)$ at the sites of $\mathrm{Sb}$ in the crystal lattice. ${ }^{[2]}$ Figure 3 presents histograms showing the percentage number of EDS spot measurements on tetrahedrite in the four

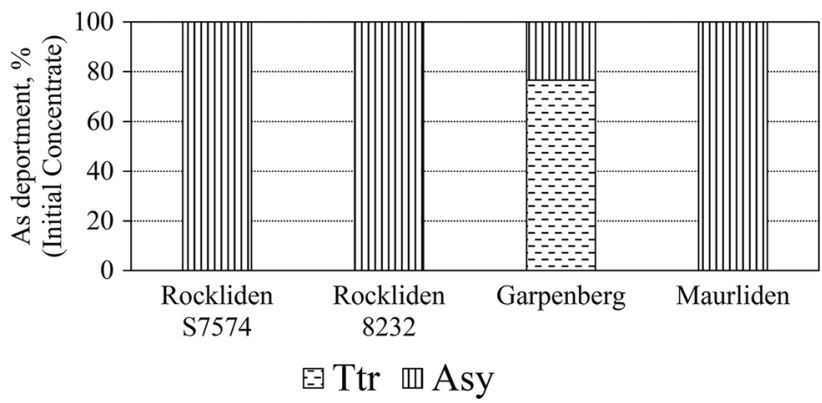

Fig. 4-As deportment in different mineral forms obtained from QEMSCAN analysis of the initial concentrates (38 to $53 \mu \mathrm{m}$ ), additionally using the chemical composition of Garpenberg concentrate from Table I.

concentrates, belonging to different levels of As content (mol pct, along $x$-axis). It shows that tetrahedrite hosts As only in the Garpenberg concentrate. As content in the tetrahedrite of the Garpenberg concentrate is up to approximately $3.5 \mathrm{~mol}$ pct in the sampled EDS measurements, whereas for the other three concentrates, As is not detected in the tetrahedrite sites.

Due to relatively low accuracy in the composition measurements during QEMSCAN (compared to the spot measurements in SEM-EDS), As-hosting tetrahedrite was not listed as a separate mineral in the SIP (mineral list in Table III). Therefore, the proportion of total As in the Garpenberg concentrate in the form of tetrahedrite was determined by deducting the amount of As in arsenopyrite (wt pct arsenopyrite obtained from QEMSCAN measurement) from the total As content (from the chemical composition of the Garpenberg concentrate in Table I). Accordingly, Figure 4 presents the mineral-wise As deportment for the four concentrates. It shows that As exists solely as arsenopyrite, except in the Garpenberg concentrate, where a major proportion of As resides in the tetrahedrite solid solution.

\section{B. Sb and As Volatilization During Roasting Experiments}

The extents of $\mathrm{Sb}$ and As removal from the isothermal roasting experiments performed between $200{ }^{\circ} \mathrm{C}$ and 700 ${ }^{\circ} \mathrm{C}$ in intervals of $100{ }^{\circ} \mathrm{C}$ (experiment details listed in Table II against the IDs 200-1, 300-1, 400-1, 500-1, 600-1 and 700-1) are shown in Figure 5.

The $\mathrm{Sb}$ and As volatilization was calculated using Eq. $[1]^{[28]}$ :

$$
\eta_{\mathrm{m}}=\left[1-\frac{C_{\mathrm{m}}^{\mathrm{f}} W_{\mathrm{f}}}{C_{\mathrm{m}}^{\mathrm{i}} W_{\mathrm{i}}}\right] \times 100, \mathrm{~m}=\mathrm{Sb}, \mathrm{As}
$$

$\eta_{\mathrm{m}}$ is the extent of element ( $\mathrm{Sb}$ or As) removal (pct) through volatilization. $W_{\mathrm{i}}$ and $W_{\mathrm{f}}$ are the weights of the initial concentrates and the roasted calcines, respectively $\left(W_{\mathrm{i}}=10 \mathrm{~g}\right) . C_{\mathrm{m}}^{\mathrm{i}}$ and $C_{\mathrm{m}}^{\mathrm{f}}$ are the wt pet Sb or As content in the initial concentrates and the roasted calcines, respectively (i, initial; $\mathrm{f}$, final, i.e., after roasting; $\mathrm{m}$, As or $\mathrm{Sb}$ ). The experimental results required for the calculation of $\eta_{\mathrm{m}}$ are listed in Table IV. 


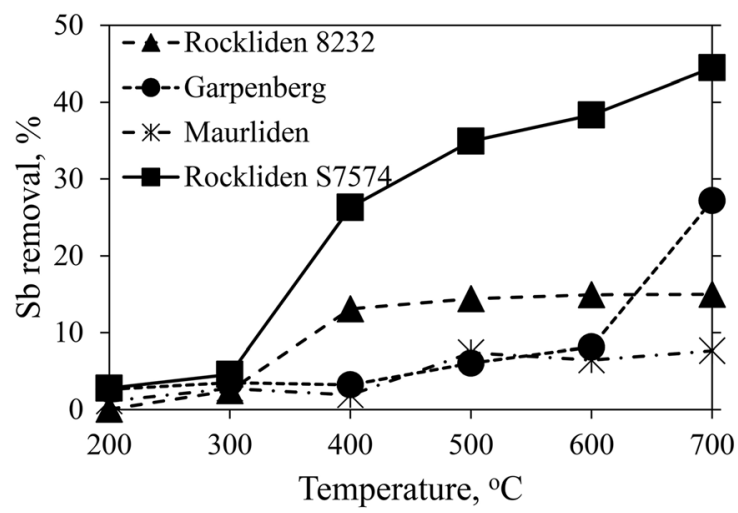

(a)

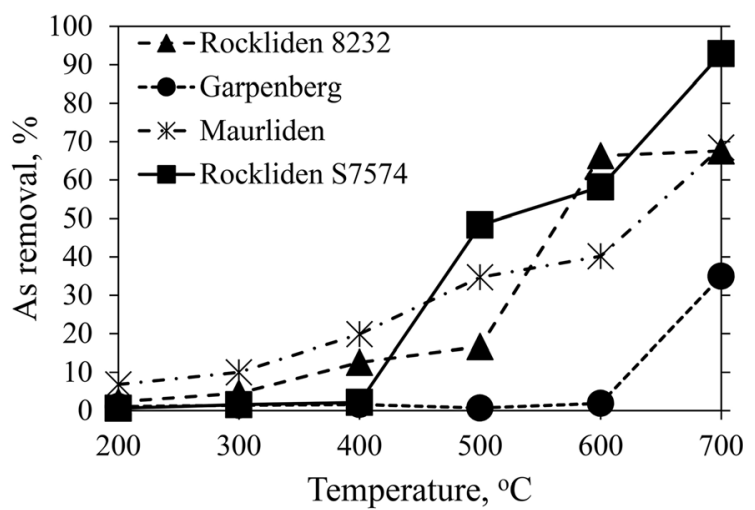

(b)

Fig. 5-Extent of impurity removal during the laboratory-scale roasting experiments performed at different temperatures on the four concentrates. (a) Sb removal; (b) As removal.

Among all the concentrates, Sb removal (pct) was the highest from the Rockliden S7574 concentrate (Figure 5(a)). Significant $\mathrm{Sb}$ removal from this concentrate was realized from $400{ }^{\circ} \mathrm{C}$ onwards. Noticeably, the Rockliden S7574 concentrate had the non-sulfosalt $\mathrm{Sb}$ mineral gudmundite (FeSbS) in a relatively high proportion (Figure 2). Investigations on the possibility of gudmundite responsible for the significant Sb volatilization from the Rockliden S7574 concentrate will be presented in a subsequent section.

In Figure 5, As removal is shown to be higher than the $\mathrm{Sb}$ removal for most of the concentrates, owing to the low volatility of $\mathrm{Sb}$ from the sulfosalt minerals. ${ }^{[43]}$ Previous experimental ${ }^{[28,32,53]}$ and model-based theoretical studies ${ }^{[54]}$ have also corroborated a high As volatilization of $>90 \mathrm{pct}$ in inert atmosphere at 700 ${ }^{\circ} \mathrm{C}$ from concentrates comprising As minerals such as enargite $\left(\mathrm{Cu}_{3} \mathrm{AsS}_{4}\right)^{[32,54]}$ and tennantite $\left(\mathrm{Cu}_{12} \mathrm{As}_{4} \mathrm{~S}_{13}\right){ }^{[28,53]}$ In the current investigation, As content at $700{ }^{\circ} \mathrm{C}$ was highest in the Maurliden concentrate, which also had the highest initial As content (Table IV). However, the extent of As removal $\left(\eta_{\mathrm{As}}, \mathrm{pct}\right)$ was least from the Garpenberg concentrate (Figure 5b), which remained insignificant up to $600{ }^{\circ} \mathrm{C}$ and increased slightly at $700{ }^{\circ} \mathrm{C}$. Notably, the Garpenberg concentrate had a substantial proportion (approximately 78 pct, Figure 4) of As in the tetrahedrite solid solution $\left((\mathrm{Cu}, \mathrm{Ag}, \mathrm{Fe}, \mathrm{Zn})_{12}(\mathrm{Sb}, \mathrm{As})_{4} \mathrm{~S}_{13}\right)$, unlike in the other three concentrates where As was found solely as arsenopyrite (FeAsS). This suggests that volatilization of As from the tetrahedrite solid solution is lower than from arsenopyrite during roasting of complex concentrates in inert atmosphere up to $700{ }^{\circ} \mathrm{C}$. Similar wide variations (between 19 and 100 pct of As volatilization after $15 \mathrm{~min}$ of laboratory-scale roasting at $700{ }^{\circ} \mathrm{C}$ in inert atmosphere) were reported by Björkman et al. ${ }^{[55]}$ consequent to the difference in initial As mineralogy. Also, Chakraborti et al..$^{[33]}$ found that at $525^{\circ} \mathrm{C}$, the As volatilization from arsenopyrite (pure or with small amounts of silica) under inert atmosphere $(\mathrm{He})$ was between 10 and 12 pct. Higher As removal of between 15 and 50 pet at $500{ }^{\circ} \mathrm{C}$ found in this work from the arsenopyrite bearing concentrates (Figure 5(b)) suggests the enhancement of As volatilization in the presence of other minerals co-existing in the complex concentrates.

\section{Phases retaining residual $A s$ and $S b$}

An another prominent effect of concentrate mineralogy, viz. the sintering tendency in the calcine during roasting, was highlighted by Prasad et al. ${ }^{[6]}$ They reported that certain combinations of minerals such as galena + arsenopyrite + pyrite and galena + tetrahedrite can lead to liquid-phase formation at around $500{ }^{\circ} \mathrm{C}$, causing early sintering. This liquid phase was found to solidify either as a single phase in case of arsenopyrite-bearing concentrates or as an intergrowth of galena and pseudo-tetrahedrite (phase resembling tetrahedrite/skinnerite, hereafter also referred to as PT) for the concentrates low in arsenopyrite. These melt fractions at $500{ }^{\circ} \mathrm{C}$ were shown to be particularly rich in $\mathrm{As}$ and $\mathrm{Sb}$ contents. This article extends those results and in Figure 6 and Table $\mathrm{V}$ further presents the micrographs and EDS compositions of the Sb- and As-bearing solidified melt phases from the $600{ }^{\circ} \mathrm{C}$ and $700{ }^{\circ} \mathrm{C}$ calcines.

In Figure 6, the liquid phases formed in the Rockliden 8232 and Garpenberg concentrates solidified as intergrowths, whereas the intergrown textures are missing in the solidified melts corresponding to the Rockliden S7574 and Maurliden concentrates. This difference in the texture of solidified melts was also evident in the micrographs pertaining to roasting at $500{ }^{\circ} \mathrm{C}^{[6]}$ and was attributed to the relatively high arsenopyrite contents in the Maurliden and Rockliden S7574 concentrates (Maurliden and Rockliden S7574 concentrates are high in As contents, Table I, and arsenopyrite is the only As mineral in these concentrates).

The mineral phases in the fine intergrown texture, M2, appearing in Figure 6 in the micrographs of Rockliden 8232 and Garpenberg concentrates are galena and pseudo-tetrahedrite (PT), established through multiple EDS measurements. Additionally, M3, the texture with a relatively coarser intergrowth, appearing in the 
Table IV. Sb and As Content and Final Weight of Calcines Obtained from the Laboratory-Scale Roasting Experiments

\begin{tabular}{|c|c|c|c|c|}
\hline Concentrate & Temperature & $C_{\mathrm{Sb}}^{\mathrm{f}}(\mathrm{Sb}, \mathrm{Wt} \mathrm{Pct})$ & $C_{\mathrm{As}}^{\mathrm{f}}(\mathrm{As}, \mathrm{Wt}$ Pct $)$ & $W_{\mathrm{f}} \cdot(\mathrm{g})$ \\
\hline \multirow[t]{7}{*}{ Rockliden S7574 } & initial & $1.36\left(C_{\mathrm{Sb}}^{\mathrm{i}}\right)$ & $0.74\left(C_{\mathrm{As}}^{\mathrm{i}}\right)$ & $10\left(W_{\mathrm{i}}\right)$ \\
\hline & $200{ }^{\circ} \mathrm{C}$ & 1.33 & 0.74 & 9.94 \\
\hline & $300{ }^{\circ} \mathrm{C}$ & 1.30 & 0.73 & 9.98 \\
\hline & $400{ }^{\circ} \mathrm{C}$ & 1.01 & 0.73 & 9.92 \\
\hline & $500{ }^{\circ} \mathrm{C}$ & 0.90 & 0.39 & 9.81 \\
\hline & $600{ }^{\circ} \mathrm{C}$ & 0.89 & 0.33 & 9.41 \\
\hline & $700{ }^{\circ} \mathrm{C}$ & 0.87 & 0.06 & 8.66 \\
\hline \multirow[t]{7}{*}{ Rockliden 8232} & initial & $1.72\left(C_{\mathrm{Sb}}^{\mathrm{i}}\right)$ & $0.44\left(C_{\mathrm{As}}^{\mathrm{i}}\right)$ & $10\left(W_{\mathrm{i}}\right)$ \\
\hline & $200{ }^{\circ} \mathrm{C}$ & 1.74 & 0.44 & 9.88 \\
\hline & $300{ }^{\circ} \mathrm{C}$ & 1.71 & 0.43 & 9.81 \\
\hline & $400{ }^{\circ} \mathrm{C}$ & 1.57 & 0.40 & 52 \\
\hline & $500{ }^{\circ} \mathrm{C}$ & 1.63 & 0.40 & 9.03 \\
\hline & $600{ }^{\circ} \mathrm{C}$ & 1.64 & 0.17 & 8.92 \\
\hline & $700{ }^{\circ} \mathrm{C}$ & 1.65 & 0.16 & 8.86 \\
\hline \multirow[t]{7}{*}{ Garpenberg } & initial & $2.04\left(C_{\mathrm{Sb}}^{\mathrm{i}}\right)$ & $0.23\left(C_{\mathrm{As}}^{\mathrm{i}}\right)$ & $10\left(W_{\mathrm{i}}\right)$ \\
\hline & $200{ }^{\circ} \mathrm{C}$ & 1.99 & 0.23 & 9.98 \\
\hline & $300{ }^{\circ} \mathrm{C}$ & 1.97 & 0.23 & 9.99 \\
\hline & $400{ }^{\circ} \mathrm{C}$ & 1.98 & 0.23 & 9.97 \\
\hline & $500{ }^{\circ} \mathrm{C}$ & 1.93 & 0.23 & 9.93 \\
\hline & $600{ }^{\circ} \mathrm{C}$ & 1.91 & 0.23 & 9.81 \\
\hline & $700{ }^{\circ} \mathrm{C}$ & 1.53 & 0.15 & 9.71 \\
\hline \multirow[t]{7}{*}{ Maurliden } & initial & $3.27\left(C_{\mathrm{Sb}}^{\mathrm{i}}\right)$ & $2.10\left(C_{\mathrm{As}}^{\mathrm{i}}\right)$ & $10\left(W_{\mathrm{i}}\right)$ \\
\hline & $200^{\circ} \mathrm{C}$ & 3.24 & 1.96 & 9.98 \\
\hline & $300{ }^{\circ} \mathrm{C}$ & 3.18 & 1.89 & 10.00 \\
\hline & $400{ }^{\circ} \mathrm{C}$ & 3.24 & 1.70 & 9.90 \\
\hline & $500{ }^{\circ} \mathrm{C}$ & 3.07 & 1.39 & 9.86 \\
\hline & $600{ }^{\circ} \mathrm{C}$ & 3.24 & 1.33 & 9.44 \\
\hline & $700{ }^{\circ} \mathrm{C}$ & 3.34 & 0.73 & 9.04 \\
\hline
\end{tabular}

Garpenberg concentrate at $600{ }^{\circ} \mathrm{C}$, comprises galena and the iss-phase ${ }^{[56,57]}$ also corroborated in Prasad et al. $^{[6]}$

The micrographs in Figure 6 also suggest an increased partial melting of galena at $600{ }^{\circ} \mathrm{C}$ and $700{ }^{\circ} \mathrm{C}$ (marked as PGn in the micrographs), subsequent to the melting initiation at approximately $500{ }^{\circ} \mathrm{C}$. ${ }^{[6]}$ Partial melting of galena is more profound in the Garpenberg and Maurliden concentrates (since these concentrates are relatively rich in $\mathrm{Pb}$, Table $\mathrm{I}$ ). The galena from this partial melting (marked as PGn in Figure 6) adjoins the intergrown phase in the micrograph for Garpenberg at $700{ }^{\circ} \mathrm{C}$. PGn also appears as entrapped, rounded, irregular shapes around the other melt phase (M1) in the micrographs for Maurliden at $600{ }^{\circ} \mathrm{C}$ and $700{ }^{\circ} \mathrm{C}$. These features in the solidified melt microstructures suggest the co-existence of multiple immiscible liquids ${ }^{[58]}$ at elevated temperatures. These immiscible liquids are found to amalgamate the unmelted/recrystallized fractions (marked as $\mathrm{S}$ in Figure 6) by filling the void spaces in the roasted calcines.

The EDS composition of the spots marked as ' $\otimes$ ' in Figure 6 for the $600{ }^{\circ} \mathrm{C}$ and $700{ }^{\circ} \mathrm{C}$ calcines are presented in Table $\mathrm{V}$. These spots belong to either PT - the pseudo-tetrahedrite phase in the intergrowths (in M2 for the Rockliden 8232 and Garpenberg concentrates) - or to M1 - the solidified single phase (for the Rockliden S7574 and Maurliden concentrates). In the $500{ }^{\circ} \mathrm{C}$ calcines, ${ }^{[6]}$ these phase fractions were found to be relatively rich in $\mathrm{As}$ and $\mathrm{Sb}$ contents. Here again, at $600{ }^{\circ} \mathrm{C}$ and $700{ }^{\circ} \mathrm{C}$ (Table V), the Sb and As contents in PT and M1 are found to be high, suggesting the retention of the unvolatilized $\mathrm{Sb}$ and $\mathrm{As}$ in these melt phases. Increasing the temperature from $600{ }^{\circ} \mathrm{C}$ to 700 ${ }^{\circ} \mathrm{C}$ led to further enrichment of $\mathrm{Sb}$ in these liquid phase fractions for all the concentrates. However, the As content was slightly reduced for the Maurliden and Garpenberg concentrates and completely diminished for the Rockliden S7574 and Rockliden 8232 concentrates from $600{ }^{\circ} \mathrm{C}$ to $700{ }^{\circ} \mathrm{C}$ (Table V). These composition measurements suggest that As was partially volatilized from the melt phase, whereas the $\mathrm{Sb}$ was mostly retained.

\section{Gudmundite Decomposition in Rockliden $\mathbf{S 7 5 7 4}$ Concentrate During Roasting at $350{ }^{\circ} \mathrm{C}$}

To ascertain the likely role of gudmundite in the early and high volatilization of $\mathrm{Sb}$ from the Rockliden S7574 concentrate compared to the other concentrates, a roasting experiment was performed at $350{ }^{\circ} \mathrm{C}$ (Experiment Type ID 350-10, Table II). This temperature was selected since gudmundite is understood to be unstable above $280{ }^{\circ} \mathrm{C} .{ }^{[50]}$ Second, there was a significant increase in $\mathrm{Sb}$ volatilization between $300{ }^{\circ} \mathrm{C}$ and $400{ }^{\circ} \mathrm{C}$ (Figure 5(a)), and an intermediate temperature $\left(350{ }^{\circ} \mathrm{C}\right)$ could possibly reveal details of the reaction initiation. Third, it would prevent the 


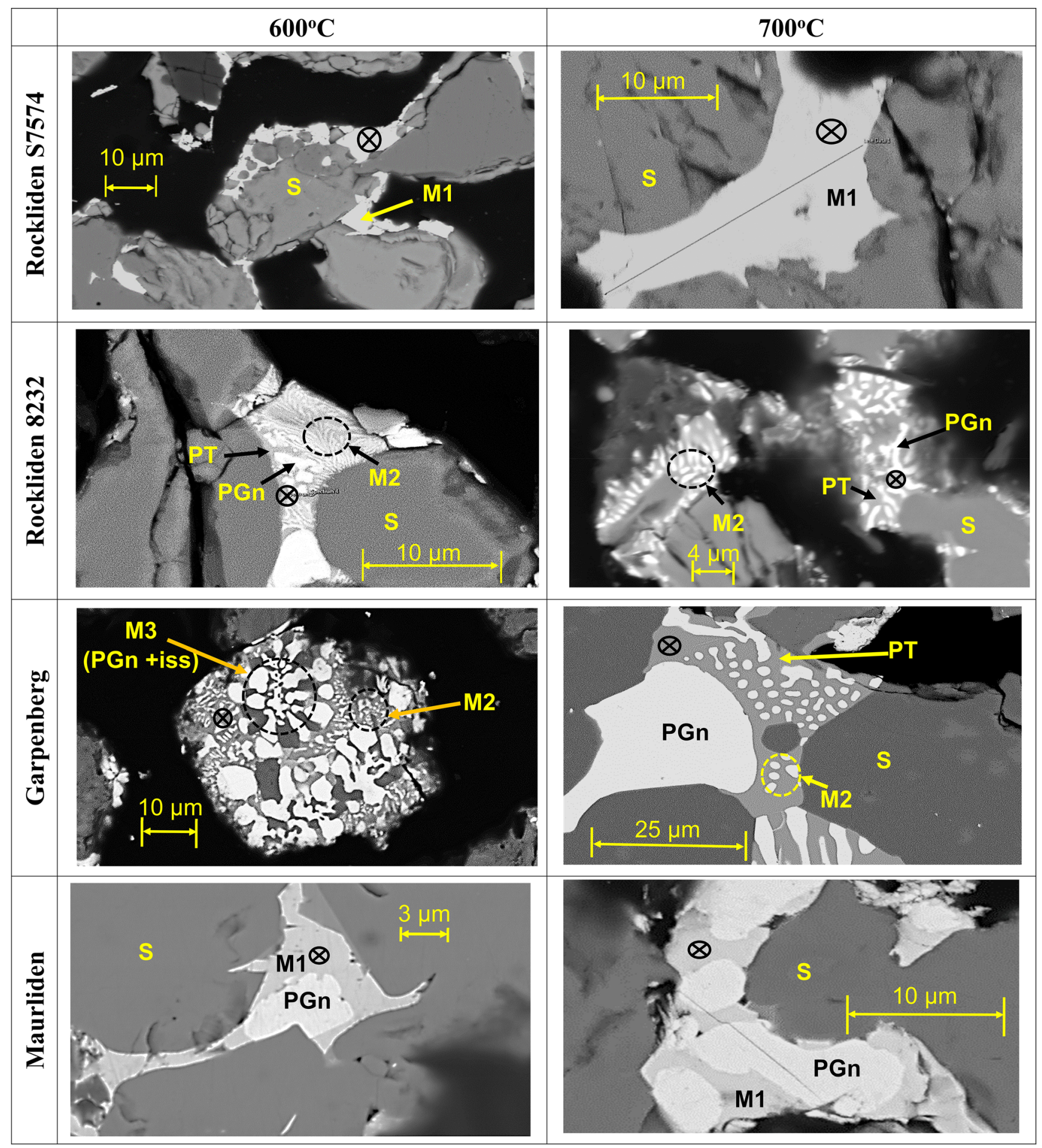

Fig. 6-BSE images showing the melt phases formed during roasting of the concentrates (38 to $53 \mu \mathrm{m})$ at $600{ }^{\circ} \mathrm{C}$ and $700{ }^{\circ} \mathrm{C}$. M1: melt solidified as a single phase (in concentrates high in arsenopyrite); M2: melt solidified as fine intergrowth of galena (undergoing partial melting) and pseudo-tetrahedrite; M3: melt solidified as coarse intergrowth of galena and iss phase; PGn: galena from partial melting; PT: pseudo-tetrahedrite; S: unmelted/recrystallized phase in the calcine. Location of EDS spot measurements are shown as ' $\otimes$ ' for the melt phase constituents bearing $\mathrm{Sb}$ and As.

transformation of other $\mathrm{As}$ and $\mathrm{Sb}$ minerals (arsenopyrite, sulfosalts and Ag antimonides), which are known to be stable at this temperature. ${ }^{[59-61]}$ The holding time in this experiment at the reaction temperature was prolonged from $70 \mathrm{~min}$ in the other experiments to $10 \mathrm{~h}$ to facilitate a noticeable microstructural evolution due to any mineralogical transformation 
Table V. EDS Composition for Measurements at Spots in the Melt Phases Bearing Sb and As Marked as ' $\otimes$ ' in Fig. 6

\begin{tabular}{|c|c|c|c|c|c|c|c|c|c|}
\hline Concentrate & $\underset{{ }^{\circ} \mathrm{C}}{\mathrm{Temp}}$ & $\begin{array}{c}\text { S, Mol } \\
\text { Pct }\end{array}$ & $\begin{array}{c}\mathrm{Cu}, \mathrm{Mol} \\
\text { Pct }\end{array}$ & $\begin{array}{c}\mathrm{Fe}, \mathrm{Mol} \\
\text { Pct }\end{array}$ & $\begin{array}{c}\mathrm{Zn}, \mathrm{Mol} \\
\text { Pct }\end{array}$ & $\begin{array}{c}\mathrm{Ag}, \mathrm{Mol} \\
\text { Pct }\end{array}$ & $\begin{array}{l}\text { As, Mol } \\
\text { Pct }\end{array}$ & $\begin{array}{l}\mathrm{Sb}, \mathrm{Mol} \\
\text { Pct }\end{array}$ & $\begin{array}{c}\mathrm{Pb}, \mathrm{Mol} \\
\text { Pct }\end{array}$ \\
\hline Rockliden & 600 & 51.7 & 1.7 & 2.9 & 0 & 0 & 3.6 & 16.7 & 23.4 \\
\hline S7574 & 700 & 50 & 2.9 & 3.5 & 0 & 0 & 0 & 15.2 & 28.4 \\
\hline Rockliden & 600 & 44.7 & 28.7 & 15.2 & 1.4 & 0.1 & 0.3 & 7.7 & 2 \\
\hline 8232 & 700 & 42.8 & 31.1 & 6.8 & 2 & 0.3 & 0 & 12.3 & 4.7 \\
\hline \multirow[t]{2}{*}{ Garpenberg } & 600 & 43 & 30.3 & 6.3 & 0 & 3.3 & 2.5 & 10.8 & 3.8 \\
\hline & 700 & 24.3 & 33.5 & 4.8 & 3.2 & 7.5 & 2.3 & 24.4 & 0 \\
\hline \multirow[t]{2}{*}{ Maurliden } & 600 & 51.6 & 2.1 & 3.4 & 1.7 & 0 & 6 & 12.8 & 22.5 \\
\hline & 700 & 52.7 & 1.1 & 1.4 & 0 & 0 & 5.4 & 15.4 & 24 \\
\hline
\end{tabular}

\section{Gudmundite in the initial concentrate}

To locate the transformed gudmundite in the roasted calcine during microscopy, its nature of occurrence in the initial concentrate was determined, to start with. The QEMSCAN study facilitated this by providing quantified details of the mineral association in the concentrates. Scanning an epoxy sample surface in QEMSCAN generated pixel-wise information (pixel-size depending on scanning resolution), which was used to quantify the complexity in microstructural textures. For this quantification, two minerals were considered associated if a pixel of one of the minerals occurred adjacent to a pixel of the other mineral. The tabulated Figure 7 is a semi-pictorial representation of the 'Association' values for all identified minerals in the Rockliden S7574 concentrate. For each mineral, the 'Association' values are listed in vertical columns, adding up to 100 pct. Each value represents the percentage number of boundary pixels of the mineral mentioned in the column header (vertical) which touch the pixels of the other mineral mentioned in the corresponding row header (horizontal). For enhanced visualization, the individual cells in Figure 7 are conditionally filled with different gray levels, such that the cell with the highest 'Association' value appears darkest, and the cell with the lowest value appears brightest. Cells with 'Association' values corresponding to the background (i.e., the portions of the epoxy material on the polished surface) are not included in this conditional cell formatting.

Noticeably, the 'Association' value of gudmundite with chalcopyrite is the highest, implying that the gudmundite-chalcopyrite is the most complex binary texture in the Rockliden S7574 concentrate. Figure 8 presents the BSE (back-scattered electron) image and the corresponding false-color image (both from QEMSCAN) of a particle hosting a typical gudmundite-chalcopyrite association found in the Rockliden S7574 concentrate.

The gudmundite-chalcopyrite association is in the form of a complex intergrowth texture, as presented in the BSE image in Figure 8(a). The false-colored image (Figure 8(b)) illustrates the pixel-wise mineral identification done in the QEMSCAN. The false color image is nearly representative of the actual texture of mineral association confirming a reasonable accuracy in mineral

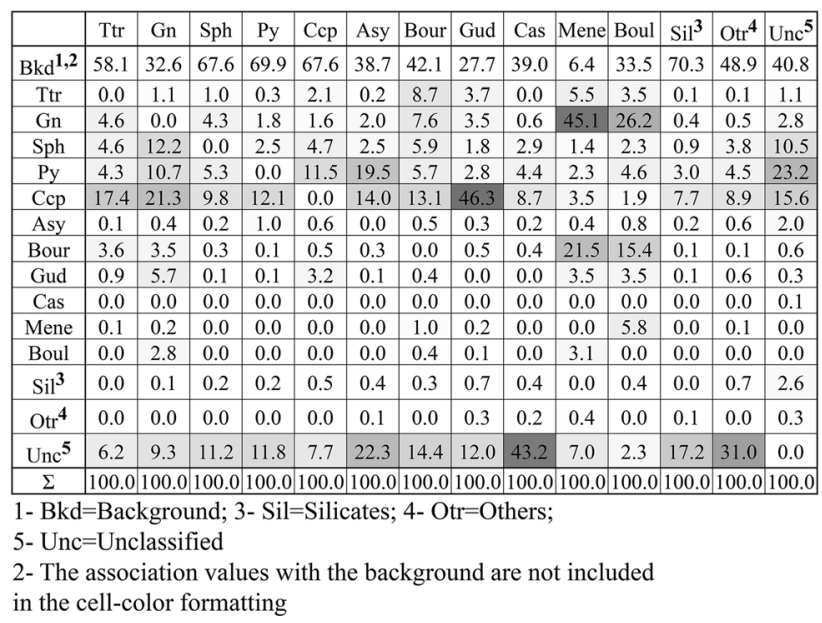

Fig. 7- 'Association' values obtained from the QEMSCAN study, quantifying the mineral association in Rockliden S7574 concentrate ( 38 to $53 \mu \mathrm{m}$ ). Two minerals are considered associated if a pixel of one of the minerals occurs adjacent to a pixel of the other mineral. Individual cells are colored/formatted on a gray scale, i.e., the cell with the lowest value appears brightest and the cell with the highest value appears darkest.

identification, which can be attributed to the low scanning resolution of $2.5 \mu \mathrm{m}$ used in the QEMSCAN study.

\section{Transformation in gudmundite after roasting at 350} ${ }^{\circ} \mathrm{C}$

SEM-EDS measurements were performed on the calcine roasted at $350{ }^{\circ} \mathrm{C}$ (Experiment Type ID 350-10, Table II) to identify the particles having mineral phases similar to the gudmundite composition, especially in the complex intergrowth texture with chalcopyrite. Figure 9 presents the BSE images of a particle in the initial concentrate and another particle in the roasted calcine $\left(350^{\circ} \mathrm{C}\right)$, both comprising mineral phases in intergrowth textures. Compositions of the intergrown phases in the two images in Figure 9 are presented in Table VI.

Gudmundite in the initial concentrate (Figure 9(a) and Table VI, Spot 2, before roasting) has a composition close to its theoretical stoichiometry: $\mathrm{Fe}=33.3 \mathrm{~mol}$ pct, $\mathrm{Sb}=33.3 \mathrm{~mol}$ pct and $\mathrm{S}=33.3 \mathrm{~mol}$ pct. The matrix mineral of the intergrowth in the initial 


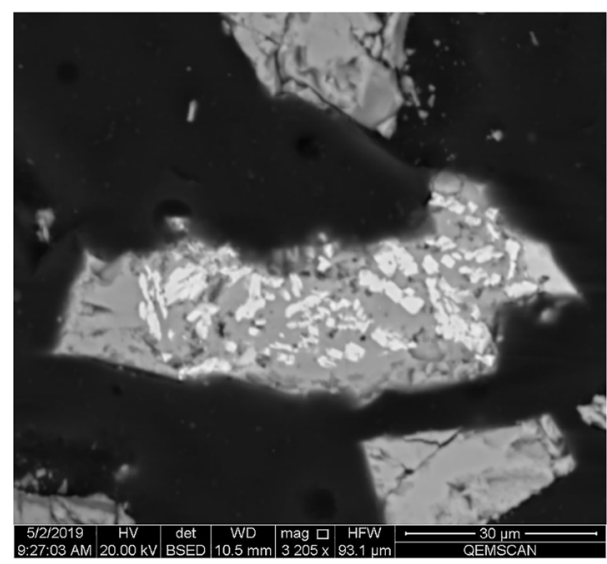

(a)

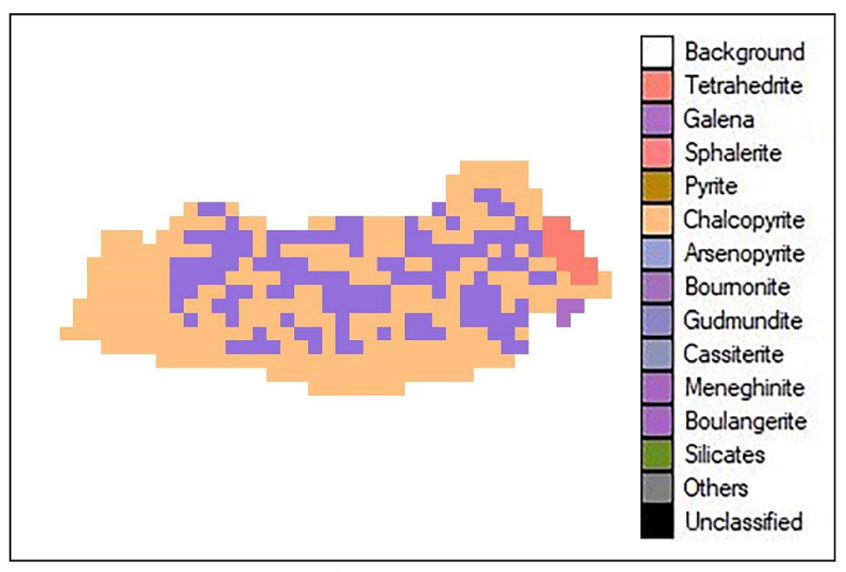

(b)

Fig. 8- (a) BSE image of a particle in Rockliden S7574 concentrate (38 to $53 \mu \mathrm{m}$ size fraction) showing the complex association between gudmundite (bright phase) and chalcopyrite (grayish phase); (b) falsely colored mineral identification image of the same particle. Both images from QEMSCAN, scanning-resolution/pixel-size being $2.5 \mu \mathrm{m}$.

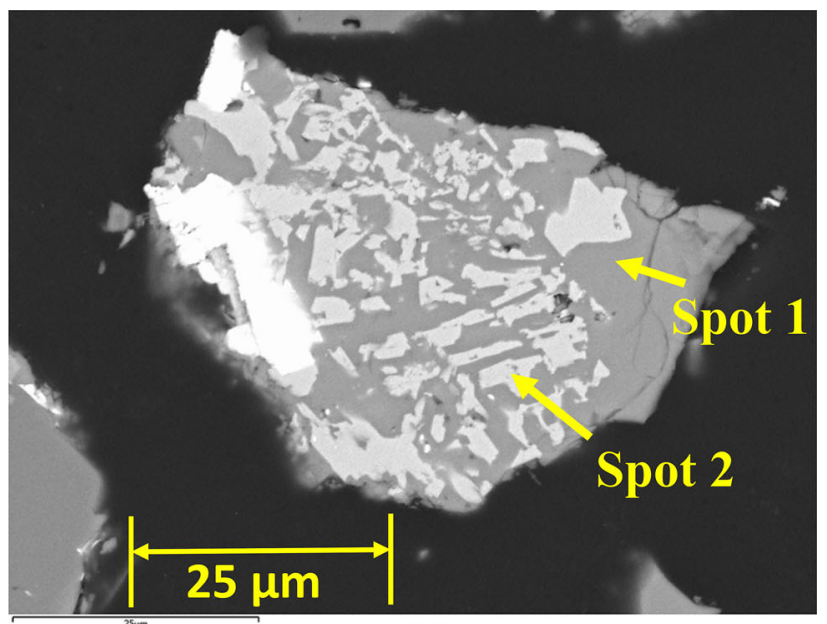

(a)

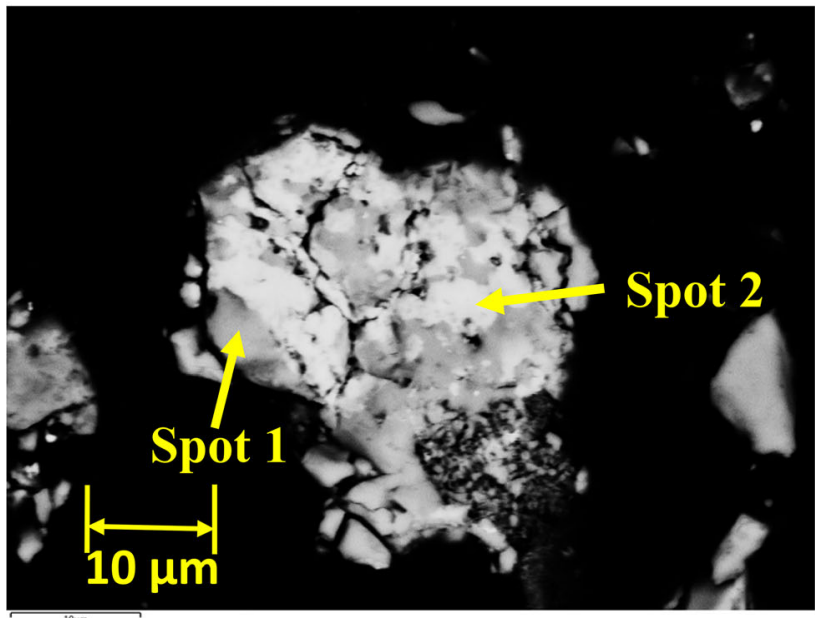

(b)

Fig. 9-Particles hosting gudmundite-chalcopyrite intergrowth belonging to Rockliden S7574 concentrate $(a)$ before roasting; $(b)$ after roasting at $350^{\circ} \mathrm{C}$. (a) and (b) Two different particles. Both images obtained from the SEM-EDS measurements. Spots in the regions of single phase with an area $\geq 16 \mu \mathrm{m}^{2}$ were selected for EDS measurements, located at the tip of the arrows shown in each image.
Table VI. Elemental Composition Obtained for the Intergrowth Phases by EDS Measurements at Spots Indicated in Fig. 9(a) for the Initial Concentrate (Rockliden S7574) and in Fig. 9(b) for the Roasted Calcine $\left(350^{\circ} \mathrm{C}\right)$

\begin{tabular}{lccccc}
\hline & \multicolumn{3}{c}{$\begin{array}{c}\text { Rockliden S7574: Chalcopyrite-Gudmundite } \\
\text { Intergrowth }\end{array}$} \\
\cline { 2 - 3 } & \multicolumn{3}{c}{ Before Roasting } & & \multicolumn{2}{c}{$\begin{array}{c}\text { After Roasting at } 350 \\
{ }^{\circ} \mathrm{C}\end{array}$} \\
\cline { 2 - 3 } \cline { 5 - 6 } Element & Spot 1 & Spot 2 & & Spot 1 & Spot 2 \\
\hline Cu, Mol Pct & 25.6 & 0.0 & & 16.2 & 7.8 \\
Fe, Mol Pct & 24.8 & 33.5 & & 30.5 & 16.8 \\
Zn, Mol Pct & 0.0 & 0.0 & & 2.4 & 0.6 \\
Sb, Mol Pct & 0.0 & 31.8 & & 0.3 & 21.6 \\
S, Mol Pct & 49.6 & 34.7 & & 50.7 & 53.1 \\
\hline
\end{tabular}

concentrate (Spot 1) is evidently chalcopyrite (closely matching with the theoretical composition of chalcopyrite: $\mathrm{Cu}=25 \mathrm{~mol} \mathrm{pct}, \mathrm{Fe}=25 \mathrm{~mol}$ pct and $\mathrm{S}=50 \mathrm{~mol}$ pct).

In the roasted calcine, the composition of Spot 1 suggests that the matrix mineral is a partially transformed chalcopyrite. This partial transformation in chalcopyrite is likely due to the formation of a solid solution (iss-phase ${ }^{[56]}$ ) during roasting at $350{ }^{\circ} \mathrm{C}$ by the assimilation of some amount of sphalerite (noticeable from a 2.4 mol pct $\mathrm{Zn}$ content). The composition at Spot 2 in the roasted calcine suggests that the Sb-bearing phase was originally gudmundite (owing to the high values of $\mathrm{Fe}$ and $\mathrm{Sb}$ contents of $16.8 \mathrm{~mol}$ pct and 21.6 mol pct, respectively).

Due to constraints in performing precise EDS measurements over smaller phase areas available in the intergrowths, a sizeable fully liberated particle of original gudmundite was located in the epoxy-mounted sample to study the nature of transformation in gudmundite due to roasting at $350{ }^{\circ} \mathrm{C}$. Figures 10 (a) through (b) presents the BSE images of this fully 


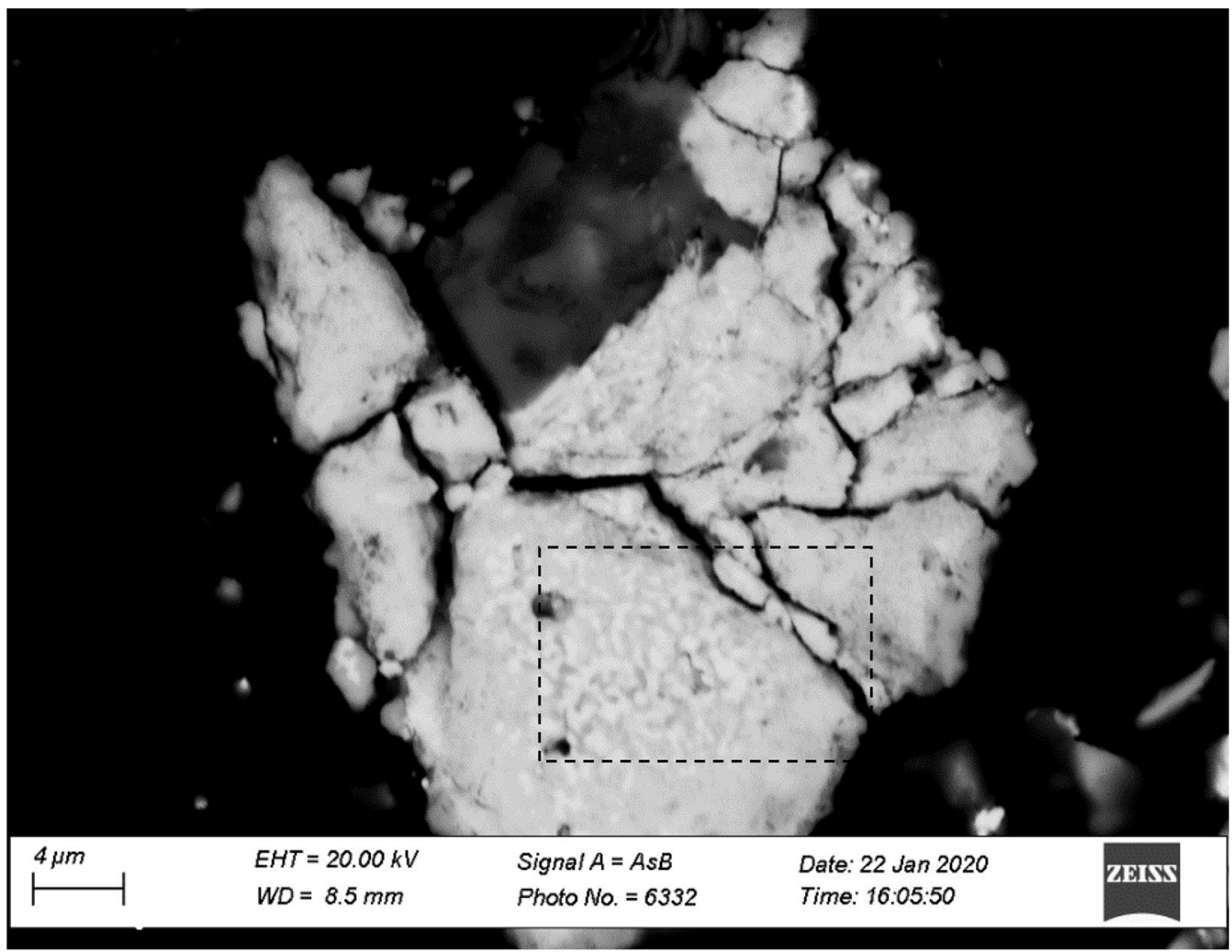

(a)

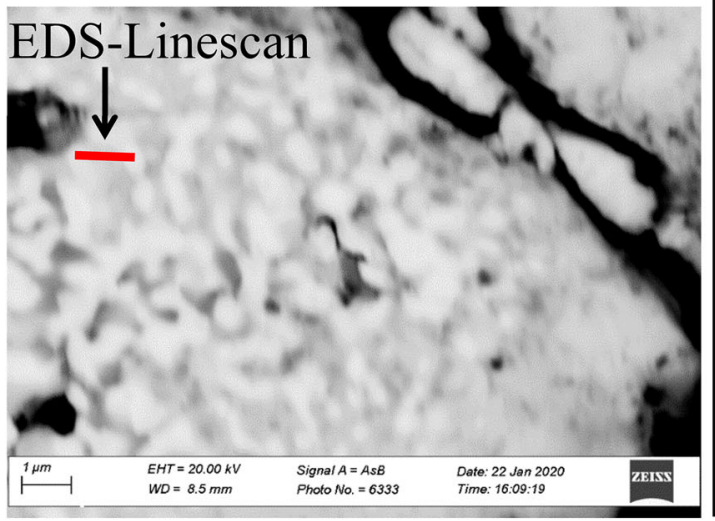

(b)

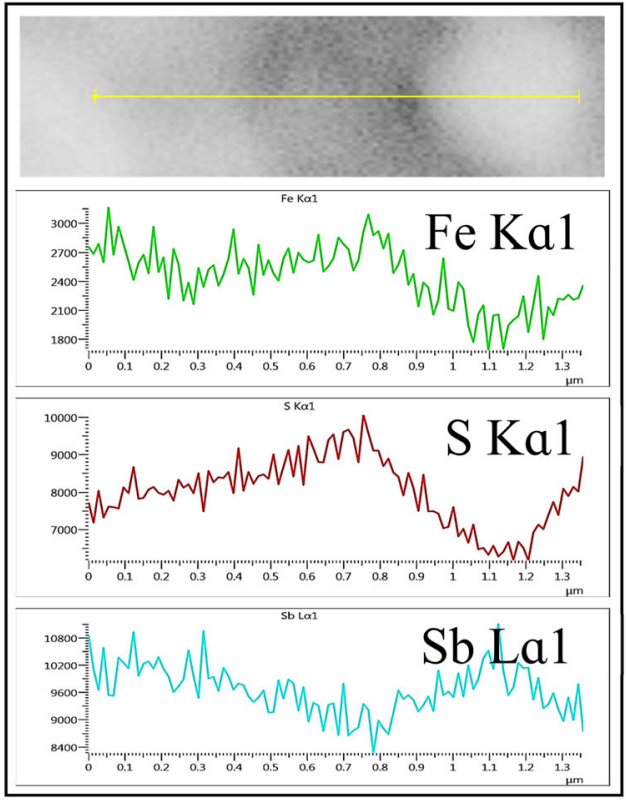

(c)

Fig. 10 - (a) BSE image of a fully liberated particle of transformed gudmundite in the $350{ }^{\circ} \mathrm{C}$ roasted calcine of Rockliden S7574 concentrate, depicting micron-scale elemental redistribution. (b) A magnified view of the rectangular area highlighted in (a), also showing the line segment over which the EDS-linescan was performed. (c) Results of the EDS-linescan (b), presenting the variation in elemental concentration (counts/s) along the line segment.

liberated transformed gudmundite particle (confirmed by numerous EDS spot measurements over this particle). Variation of the gray level over the particle, especially in the highlighted rectangular area (further magnified in Figure 10(b)), suggests a micron-scale elemental redistribution in gudmundite due to roasting. It was not possible to correctly determine the compositions at the spots with different gray levels due to small size of the uniform phase fields. However, an EDSlinescan was performed to assess the nature of elemental 


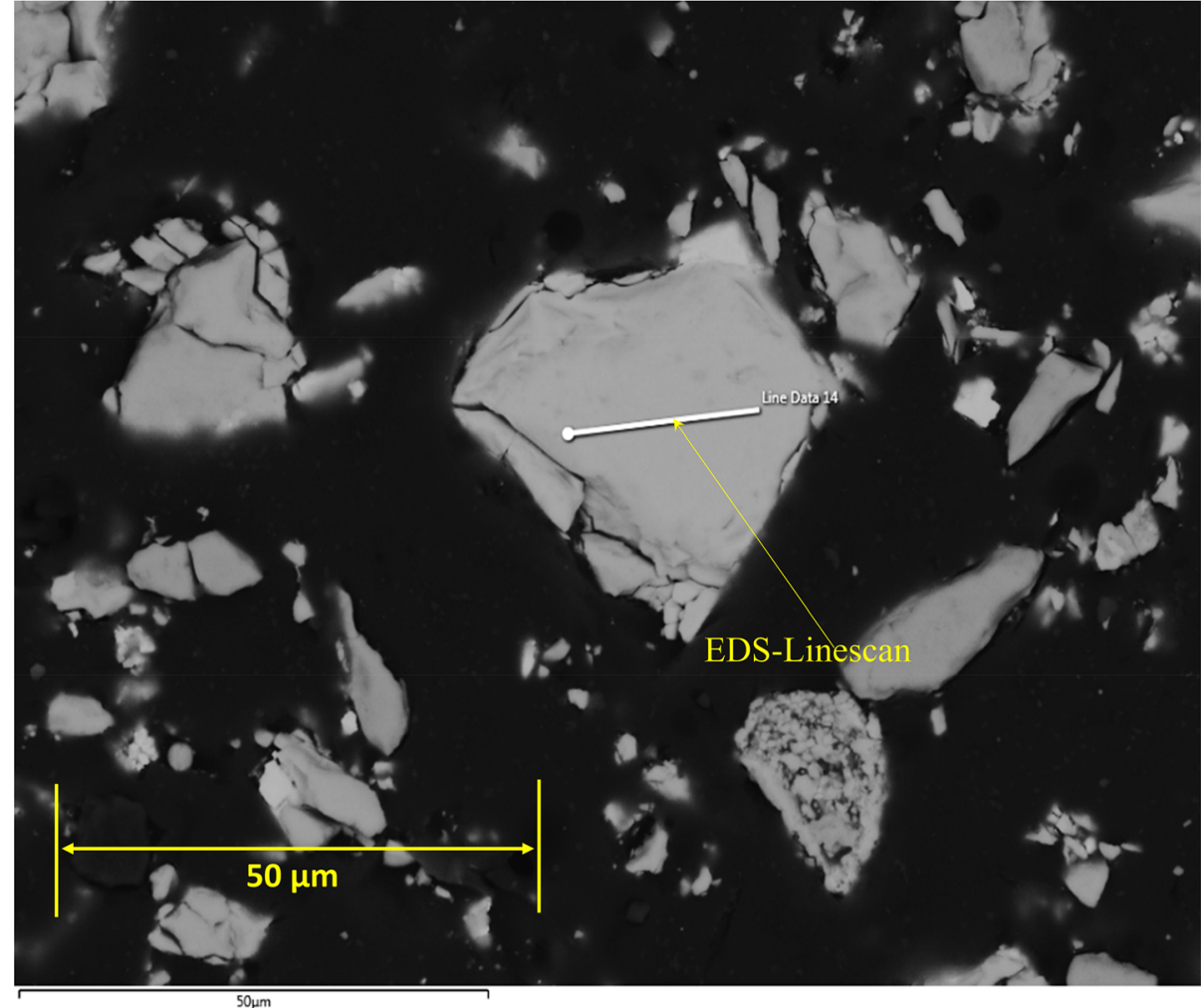

(a)

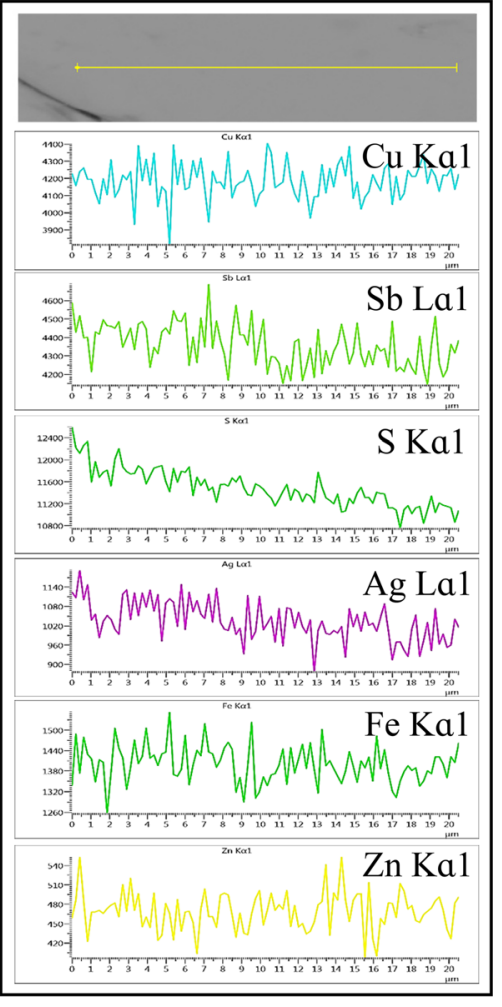

(b)

Fig. 11-(a) BSE image and (b) EDS-linescan results for a fully liberated particle of tetrahedrite in the $350{ }^{\circ} \mathrm{C}$ roasted calcine of Rockliden S7574 concentrate.

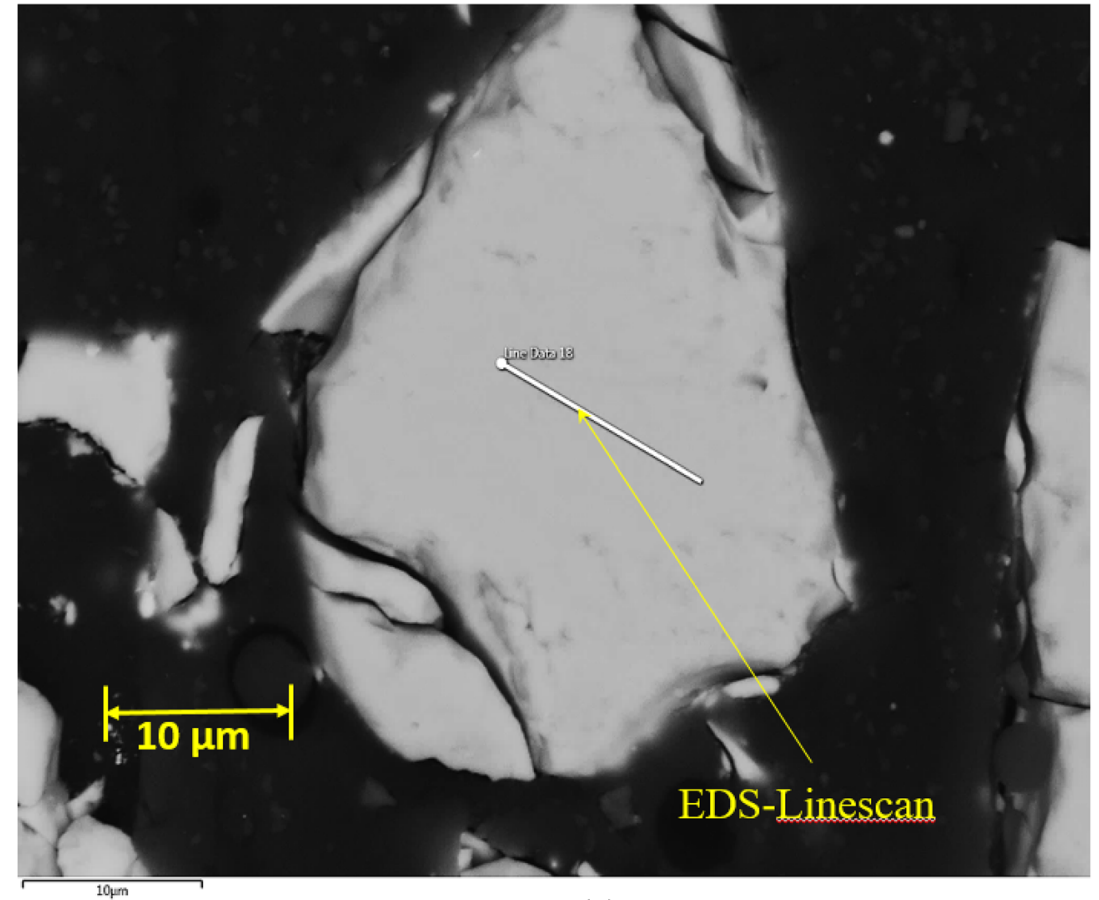

(a)

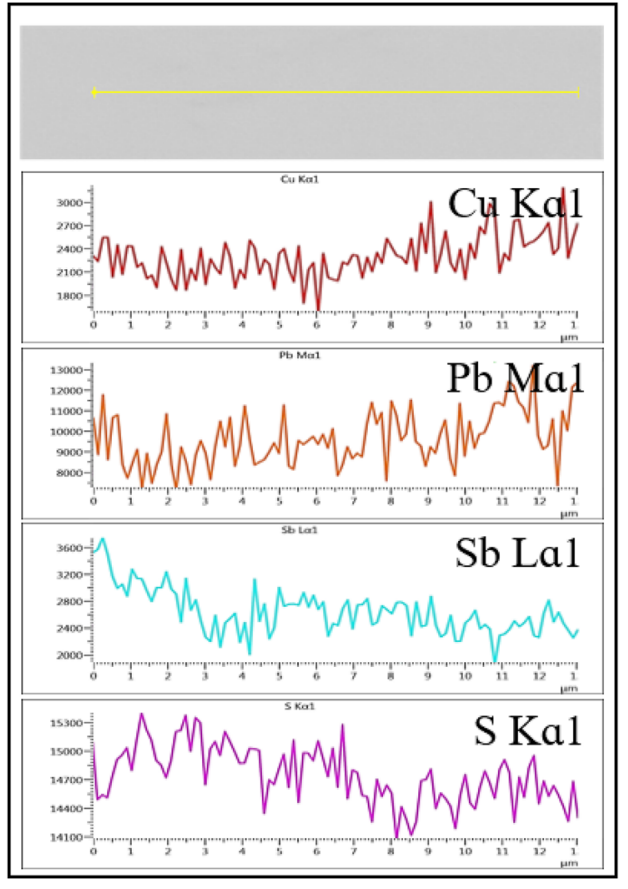

(b)

Fig. 12 - (a) BSE image and (b) EDS-linescan results for a fully liberated particle of bournonite in the $350{ }^{\circ} \mathrm{C}$ roasted calcine of Rockliden S7574 concentrate. 
redistribution, with results presented in Figure 10(c) as plots of element concentration (in counts/s) over the measured line segment. The EDS-linescan shows that the brighter areas in Figure 10(b) are Sb-rich, thereby suggesting the exodus of $\mathrm{Sb}$ from the gudmundite (FeSbS). This observation is in agreement with the previous findings of Clark et al ${ }^{[50]}$ that decomposition of gudmundite takes place via Eq. [2] above $280^{\circ} \mathrm{C}$.

$$
\mathrm{FeSbS}(\mathrm{s}) \rightarrow \mathrm{Fe}_{1-x} \mathrm{~S}(\mathrm{~s})+\mathrm{Sb}(\mathrm{s})
$$

\section{Transformation in Other Sb Minerals After Roasting at $350{ }^{\circ} \mathrm{C}$}

Fully liberated particles of the other Sb-bearing minerals - tetrahedrite and bournonite (Figure 2) in the $350{ }^{\circ} \mathrm{C}$ calcine of the Rockliden $\mathrm{S} 7574$ concentrate-were also examined in SEM-EDS for the detection of any transformation. BSE images of tetrahedrite (Figure 11) and bournonite (Figure 12(a)) do not show any distinguishable gray-level variation in these mineral particles, suggesting a low probability of transformation in these two minerals. The corresponding EDS-linescan results (Figures 11(b) and 12(b)) further confirm that there is no clear elemental redistribution in tetrahedrite and bouronite at $350{ }^{\circ} \mathrm{C}$, unlike in gudmundite.

Therefore, gudmundite is the only $\mathrm{Sb}$ mineral that underwent transformation at $350{ }^{\circ} \mathrm{C}$, decomposing into $\mathrm{Fe}_{1-x} \mathrm{~S}(\mathrm{~s})$ and $\mathrm{Sb}(\mathrm{s})$. Despite the lack of clarity about the exact reaction mechanism of $\mathrm{Sb}$ volatilization subsequently from $\mathrm{Sb}(\mathrm{s})$, findings from the roasting experiment at $350{ }^{\circ} \mathrm{C}$ confirm the initial hypothesis proposed in this work. The Rockliden S7574 concentrate being relatively high in gudmundite (Figure 2) and undergoing significant $\mathrm{Sb}$ volatilization above $300{ }^{\circ} \mathrm{C}$ (Figure 5(a)) suggests that $\mathrm{Sb}$ in gudmundite gets effectively volatilized during roasting in inert atmosphere. This benign attribute of gudmundite during roasting may also be relevant in a geometallurgical context, where during flotation in mineral processing the misplacement of gudmundite in a $\mathrm{Cu}$-rich stream is considered troublesome. ${ }^{[48]}$

\section{CONCLUSIONS}

Prominent findings from the laboratory-scale roasting experiments performed over four different $\mathrm{Cu}$-rich polymetallic concentrates in inert atmosphere are as follows:

(1) Roasting up to $700{ }^{\circ} \mathrm{C}$ in inert atmosphere generally leads to a higher As volatilization compared to $\mathrm{Sb}$ volatilization. As volatilization of up to approximately 95 pct could be achieved as against $\mathrm{Sb}$ volatilization of a maximum 45 pct in the laboratory-scale experiments. However, if As is primarily in a tetrahedrite solid solution $\left((\mathrm{Cu}, \mathrm{Ag}, \mathrm{Fe}, \mathrm{Zn})_{12}(\mathrm{~S}-\right.$ b,As) $)_{4} \mathrm{~S}_{13}$, the As volatilization up to $700{ }^{\circ} \mathrm{C}$ from such a concentrate remains insignificant.

(2) During roasting, $\mathrm{Sb}$ and As from the different minerals in the concentrate join a low-melting liquid phase above $500{ }^{\circ} \mathrm{C}$, formed because of characteristic physicochemical mineral interactions in complex polymetallic concentrates. Increased partial melting of galena with temperature leads to enlargement of the melt phase. This melt phase gets enriched in $\mathrm{Sb}$ with an increase in temperature, retaining most of the initial $\mathrm{Sb}$. However, there is noticeable As volatilization from the melt phase with the temperature approaching $700{ }^{\circ} \mathrm{C}$.

(3) The $\mathrm{Sb}$ volatilization from the sulfosalt minerals is insignificant up to $700{ }^{\circ} \mathrm{C}$ in inert atmosphere. In contrast, substantial $\mathrm{Sb}$ volatilization takes places from gudmundite starting from between $300{ }^{\circ} \mathrm{C}$ and $400{ }^{\circ} \mathrm{C}$. Sb volatilization from gudmundite is initiated by its thermal decomposition into $\mathrm{Fe}_{1-x} \mathrm{~S}(\mathrm{~s})$ and $\mathrm{Sb}(\mathrm{s})$ below $400{ }^{\circ} \mathrm{C}$.

(4) From a geometallurgical perspective, the $\mathrm{Sb}$ volatilization characteristics of a $\mathrm{Sb}$ mineral such as gudmundite during roasting can be relevant information. For instance, the problem of gudmundite misplacement in the $\mathrm{Cu}$ - and $\mathrm{Pb}$-rich flotation streams during mineral processing can be re-assessed, considering the beneficial attribute of gudmundite undergoing significant $\mathrm{Sb}$ volatilization during roasting in inert atmosphere.

\section{ACKNOWLEDGMENTS}

The authors thank (1) CAMM $^{2}$ (Center for Advanced Mining and Metallurgy) at Luleå Tekniska Universitet, Sweden, for the financial support; (2) Swedish Strategic Innovation Program STRIM (a joint venture of Vinnova, Formas and the Swedish Energy Agency) for the financial support; (3) personnel at Boliden $\mathrm{AB}$ for providing concentrate samples, chemical analyses and QEMSCAN analyses; (4) Ore Geology at Luleå Tekniska Universitet, Sweden, for providing concentrate samples they produced through laboratory-scale flotation in a previous study.

\section{FUNDING}

Open access funding provided by Lulea University of Technology.

\section{OPEN ACCESS}

This article is licensed under a Creative Commons Attribution 4.0 International License, which permits use, sharing, adaptation, distribution and reproduction in any medium or format, as long as you give appropriate credit to the original author(s) and the source, provide a link to the Creative Commons licence, and indicate if changes were made. The images or other third party material in this article are included in the article's Creative Commons licence, unless indicated 
otherwise in a credit line to the material. If material is not included in the article's Creative Commons licence and your intended use is not permitted by statutory regulation or exceeds the permitted use, you will need to obtain permission directly from the copyright holder. To view a copy of this licence, visit http://creativec ommons.org/licenses/by/4.0/.

\section{REFERENCES}

1. C. Wanhainen, M. Kontturi, and O. Martinsson: Appl. Earth Sci., 2003, vol. 112, pp. 260-67.

2. J. Sandecki and O. Amcoff: Neues Jahrb. fur Mineral. Abhandlungen, 1981, vol. 141, pp. 324-40.

3. J. Sandecki: Neues Jahrb. fur Mineral. Monatshefte, 1983, pp 365-74.

4. C. Montelius, R.L. Allen, S.-A. Svenson, and P. Weihed: $G F F$, 2007, vol. 129, pp. 177-96.

5. F. Minz, N.-J. Bolin, P. Lamberg, and C. Wanhainen: Miner. Eng., 2013, vol. 52, pp. 95-103.

6. P.N. Prasad, A. Lennartsson, and C. Samuelsson: Metall. Mater. Trans. B, 2020, vol. 51B, pp. 1446-59.

7. D. Filippou, P. St-Germain, and T. Grammatikopoulos: Miner. Process. Extr. Metall. Rev., 2007, vol. 28, pp. 247-98.

8. P. Grez, R. Schrebler, R. Henríquez, R. Cisternas, M. Orellana, and R. Córdova: J. Electroanal. Chem., 2009, vol. 628, pp. 134-43.

9. S. Wang: $J O M, 2004$, vol. 56 , pp. 34-37.

10. C. Samuelsson, and B. Björkman: in Handbook of Recycling, E. Worrell and M.A. Reuter, eds., Elsevier, Amsterdam, 2014, pp. 85-94.

11. R. Padilla, D. Girón, and M.C. Ruiz: Hydrometallurgy, 2005, vol. 80 , pp. $272-79$.

12. M.J. Correia, J. Carvalho, and J. Monhemius: Miner. Eng., 2001, vol. 14 , pp. 185-95.

13. M.J.N. Correia, J.R. Carvalho, and A.J. Monhemius: Hydrometallurgy, 2000, vol. 57, pp. 167-79.

14. S. Guy, C.P. Broadbent, G.J. Lawson, and J.D.J. Jackson: Hydrometallurgy, 1983, vol. 10, pp. 243-55.

15. T. Havlik, Z. Ivanova, J. Dvorscikova, and R. Kammel: Met. (Berlin, West), 1999, vol. 53, pp. 390-94.

16. T. Havlik, and R. Kammel: Met. (Berlin, West), 2000, vol. 54, pp. 26-29.

17. P. Baláž and M. Achimovičová: Hydrometallurgy, 2006, vol. 84 , pp. $60-68$.

18. P. Baláž and M. Achimovičová: Int. J. Miner. Process., 2006 , vol. 81 , pp. 44-50.

19. P. Balaz, R. Kammel, and C. Villachica: Met. (Berlin, West), 2001, vol. 55, pp. 196-200.

20. S.A. Awe, C. Samuelsson, and Å. Sandström: Hydrometallurgy, 2010, vol. 103, pp. 167-72.

21. I. Wilkomirsky, F. Parada, A. Ulloa, A. Carrasso, and L. Jeraldo: in Proc. IV Int. Conf. Clean Technol. Min. Ind., vol. 2, Concepción Univ. Press, 1998, pp. 613-21.

22. A. Bjornberg, S.A. Holmstrom, and G. Lindkvist: in US Pat. 4,626,279, 1986.

23. M. Devia, I. Wilkomirsky, and R. Parra: Mining Metall. Explor., 2012, vol. 29, pp. 121-28.

24. R. Padilla, and M.C. Ruiz: in Drying, Roasting, Calcining Miner., T. Battle, J. Downey, L. May, B. Davis, N. Neelameggham, S. Sanchez-Segado, and C. Pistorius, eds., Springer, Berlin, 2016, pp. $43-50$

25. P.R. Taylor and T.A.R. Putra: in Celebrating Megascale, P.J. Mackey, E.J. Grimsey, R.T. Jones, and G.A. Brooks, eds., Springer, Berlin, 2014, pp. 197-211.

26. W. Hong Lu and Z. Lan Yin: Int. J. Miner. Process., 2016 vol. 153 , pp. 1-7.
27. S. Shibuya, C. Tokoro, and T. Okura: in Proc. 7th Eur. Metall. Conf., 2013, pp. 111-22.

28. K. Haga, B. Altansukh, and A. Shibayama: Mater. Trans., 2018, vol. 59, pp. 1396-1403.

29. A. Holmström: Ph.D. Thesis, R. Inst. Technol., Dep. Prod. Technol. (Stockholm), 1988.

30. I. Wilkomirsky, R. Parra, F. Parada, and E. Balladares: in COM 2014 - Conf. Metall. Proc., B. Davis, ed., Metall. Mater. Soc., Can. Inst. Min, Metall. Pet., 2014.

31. R. Padilla, A. Aracena, and M.C. Ruiz: Metall. Mater. Trans. B, 2012, vol. 43B, pp. 1119-26.

32. R. Padilla, Y. Fan, and I. Wilkomirsky: Can. Metall. Q., 2001, vol. 40 , pp. $335-42$

33. N. Chakraborti and D.C. Lynch: Metall. Trans. B, 1983, vol. 14, pp. 239-51.

34. A. Vian, C. Iriate, and A. Romero: Ind. Eng. Chem. Process Des. Dev., 1963, vol. 2, pp. 214-23.

35. G. Ruihua: Yunnan Chem. Technol., 1995, vol. 3.

36. Y. Yang and Y.X. Hua: TransMet. Soc. China Engl. Ed., 2003, vol. 13, pp. 221-25.

37. W. Qin, H. Luo, W. Liu, Y. Zheng, K. Yang, and J. Han: J. Cent. South Univ., 2015, vol. 22, pp. 868-73.

38. F. Zhu, Y. Hua, and Y. Meng: Miner. Process. Extr Metall., 2005, vol. 114, pp. 219-23

39. R. Padilla, G. Ramírez, and M.C. Ruiz: Metall. Mater. Trans. B, 2010, vol. 41, pp. 1284-92

40. Ž. Živković, N. Štrbac, D. Živković, D. Grujičić, and B. Boyanov: Thermochim. Acta, 2002, vol. 383, pp. 137-43.

41. R. Padilla, A. Aracena, and M.C. Ruiz: J. Min. Metall. B Metall., 2014, vol. 50, pp. 127-32.

42. Y.X. Hua, Y. Yang, and F.L. Zhu: J. Mater. Sci. Technol., 2003, vol. 19 , pp. 619-22.

43. L. Komorova, A. Holmstrom, and I. Imris: Scand. J. Metall., 1985, vol. 14, pp. 103-12.

44. T. Li, and J.P. Hager: in Reinhardt Schuhmann Int. Symp. Innovative Technol. React. Des. Extr. Metall., Proc. Symp., D.R. Gaskell, J.P. Hager, J.E. Hoffmann, and P.J. Mackey, eds., 1986, pp. 845-68.

45. J.E. Mauser: Metall. Trans. B, 1982, vol. 13, pp. 511-13.

46. G. Lindkvist and A. Holmstrom: Adv. Sulfide Smelt., 1983, vol. 2, pp. 451-72.

47. S. Nakazawa, A. Yazawa, and F.R.A. Jorgensen: Metall. Mater. Trans. A Phys. Metall. Mater. Sci., 1999, vol. 30, pp. 393-401.

48. F.E. Minz, N.-J. Bolin, P. Lamberg, K. Bachmann, J. Gutzmer, and C. Wanhainen: Miner. Eng., 2015, vol. 82, pp. 125-35.

49. T. Lager and E. Forssberg: Trans. Inst. Min. Metall. Sect. C-Mineral Process. Extr. Metall., 1990, vol. 99, pp. 54-61.

50. A.H. Clark: Mineral. Mag. J. Mineral. Soc., 1966, vol. 36, pp. $1123-25$.

51. SS EN ISO 17294-2, Swed. Stand., Eur. Comm. Stand., 2016.

52. S.E. Long and T.D. Martin: EPA Method 200.8, U.S. Environ. Prot. Agency, 1994

53. Z. Yin, W. Lu, and H. Xiao: Vacuum, 2014, vol. 101, pp. 350-53.

54. J. Tapia and I. Wilkomirsky: Min. Metall. Explor., 2001, vol. 18, pp. $154-61$.

55. B. Björkman, U. Degerstedt, B. Lindblom, and C. Samuelsson: in Extr. Process. Treat. Minimization Wastes, Proc. Int. Symp., J. Hager, ed., Miner. Met. Mater. Soc., 1994, pp. 825-42.

56. S. Kojima and A. Sugaki: Econ. Geol., 1985, vol. 80, pp. 158-71.

57. S. Kojima and A. Sugaki: Mineral. J., 1984, vol. 12, pp. 15-28.

58. N. Derimow and R. Abbaschian: Entropy, 2018, vol. 20, p. 890.

59. A.G. Tomkins, D.R.M. Pattison, and B.R. Frost: J. Petrol., 2007, vol. 48, pp. 511-35.

60. B.R. Frost, J.A. Mavrogenes, and A.G. Tomkins: Can. Mineral., 2002, vol. 40 , pp. $1-18$.

61. A.G. Tomkins, B.R. Frost, and D.R.M. Pattison: Can. Mineral., 2006, vol. 44, pp. 1045-62.

Publisher's Note Springer Nature remains neutral with regard to jurisdictional claims in published maps and institutional affiliations. 